\title{
GOVERNMENT SUPPORT OF BANKS AND BANK LENDING
}

\author{
William Bassett \\ Selva Demiralp \\ Nathan Lloyd
}

Working Paper 1611

October 2016

This Working Paper is issued under the supervision of the ERF Directorate. Any opinions expressed here are those of the author(s) and not those of the Koç University-TÜSİAD Economic Research Forum. It is circulated for discussion and comment purposes and has not been subject to review by referees. 


\title{
Government Support of Banks and Bank Lending ${ }^{1}$
}

\author{
William Bassett \\ Deputy Associate Director \\ Board of Governors of the Federal Reserve System \\ 20th Street and Constitution Avenue N.W. \\ Washington, D.C. 20551 USA \\ Phone: +1 2027365644 \\ william.bassett@frb.gov \\ Selva Demiralp ${ }^{2}$ \\ Associate Professor \\ Koc University \\ Rumeli Feneri Yolu \\ Sariyer, Istanbul, 34450 Turkey \\ Phone: +90 2123381842 \\ sdemiralp@ku.edu.tr

\section{Nathan Lloyd \\ Board of Governors of the Federal Reserve System \\ 20th Street and Constitution Avenue N.W. \\ Washington, D.C. 20551 USA \\ Phone: 202-973-6950 \\ Nathan.S.Lloyd@frb.gov \\ Abstract}

The extraordinary steps taken by governments during the 2007-2009 financial crisis to prevent the failure of large financial institutions and support credit availability have invited heated debate. This paper comprehensively reviews empirical assessments of the benefits of those programs - such as their effectiveness in reducing bank failures or supporting new lendingintroduces a combined dataset of five key programs that provided term debt or equity to banks in the U.S., and assesses the effects of such support on lending by U.S. banks. The results, using an instrumental variable approach, suggest that bank loans did not increase at institutions receiving government support.

JEL Codes: G11, G21, E58

Keywords: Bank Loans, TAF, TARP, Capital Purchase Program

\footnotetext{
${ }^{1}$ Disclaimer: The views expressed are those of the authors and do not necessarily reflect the views of the Board of Governors or anyone else associated with the Federal Reserve System.

${ }^{2}$ Corresponding Author. Tel: +90 2123381842 Fax: +90 2123381653
} 


\title{
Government Support of Banks and Bank Lending
}

\section{September 2016}

\begin{abstract}
The extraordinary steps taken by governments during the 2007-2009 financial crisis to prevent the failure of large financial institutions and support credit availability have invited heated debate. This paper comprehensively reviews empirical assessments of the benefits of those programs - such as their effectiveness in reducing bank failures or supporting new lendingintroduces a combined dataset of five key programs that provided term debt or equity to banks in the U.S., and assesses the effects of such support on lending by U.S. banks. The results, using an instrumental variable approach, suggest that bank loans did not increase at institutions receiving government support.
\end{abstract}

JEL Codes: G11, G21, E58

Keywords: Bank Loans, TAF, TARP, Capital Purchase Program 


\section{Introduction}

The worldwide financial crisis of 2007 to 2009 had many stages and wide ranging effects on both financial markets and global economic output. Many ramifications of those disruptions continue to vex consumers, businesses, and policymakers almost a decade later. When securitization and interbank funding markets began to seize during the second half of 2007, loans held by commercial banks (the solid line in figure 1) initially expanded even as the economy weakened and financial strains mounted. This growth reflected in part loans that banks had intended to securitize but instead were forced to hold on their balance sheet and drawdowns of pre-existing loan commitments by businesses and households (the dashed line in figure 1). However, that expansion put additional pressure on banks, whose balance sheets were already strained by mounting losses.

As illustrated in figure 2, greater than usual numbers of banks in the Federal Reserve's Senior Loan Officer Opinion Survey reported having tightened lending policies between 2007 and 2009 because of concerns about their liquidity and capital positions (Bassett and Covas, 2013). Indeed, banks tightened their lending policies over the crisis period to an even greater extent than would have been expected given the developments in financial markets and the economy (Bassett et al., 2014). Predictably, bank lending declined steeply starting in October 2008 and did not resume growing until mid-2011, as many factors restrained the supply of credit and depressed loan demand over that period.

Central banks recognized early in the crisis period the danger that an adverse feedback loop could develop if troubles in the financial sector spilled over to the real economy. To limit 
that damage, they took extraordinary steps to inject liquidity into the financial system. ${ }^{3}$ When those measures proved insufficient to staunch the crisis, some national governments took steps to recapitalize their banking sectors. Such measures were designed not only to prevent the disorderly failure of multiple large financial institutions, but also to support the continued extension of credit to businesses and households.
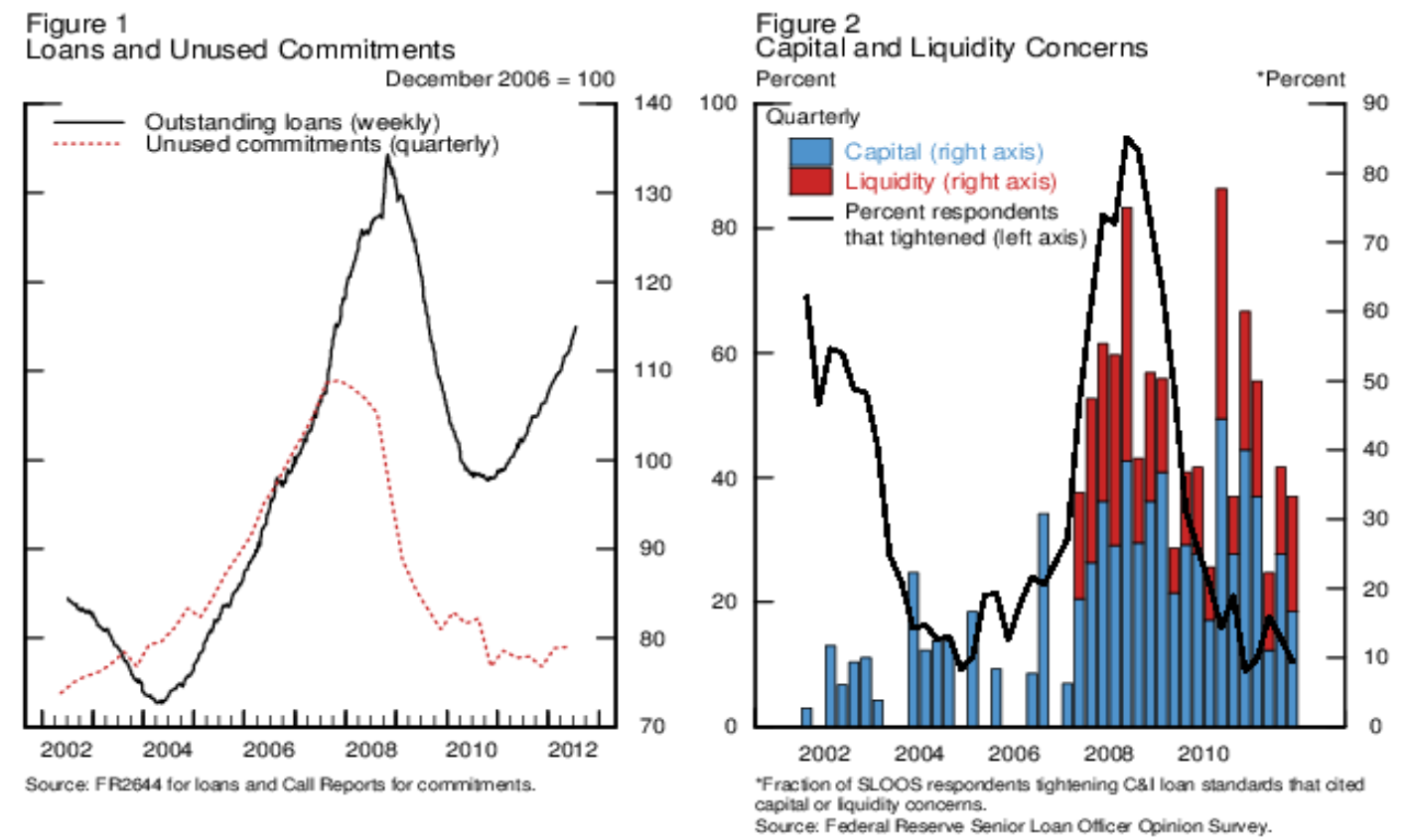

Because of both the enormous size and the unconventional nature of the policies enacted to mitigate the damage done by the financial crisis, the wisdom and efficacy of those programs has been the subject of heated debate among financial professionals, politicians, and

\footnotetext{
${ }^{3}$ For instance, the press release following the Federal Open Market Committee meeting on September 18, 2007, stated, "Today's action is intended to help forestall some of the adverse effects on the broader economy that might otherwise arise from the disruptions in financial markets and to promote moderate growth over time."
} 
the general public. ${ }^{4}$ That debate intensified in light of the protracted decline in bank lending and the uneven economic recovery after the crisis began to ebb, with some wondering whether the benefits of the programs exceeded their costs. Those costs include a potential increase in moral hazard, as some argued that financial firms may in the future take similar risks in anticipation of another "bailout."

This paper makes three contributions. The next section is a comprehensive and critical review of the existing literature on crisis-era lending and equity programs. The third section describes our new dataset incorporating five of the largest crisis-era programs, which will allow future researchers to study more-easily how banks used them interchangeably, and expand the number of studies of the less-well-known programs. The fourth section uses an instrumental variable approach to study the joint effect on bank lending of those programs.

We combined five crisis-era support programs into a single dataset, which we hope will spur future research. The dataset includes two equity-purchase initiatives - the Capital Purchase Program (CPP) and the Small Business Lending Facility (SBLF)—which were funded by the U.S. Treasury's Troubled Asset Relief Program (TARP). The long-term debt issuance under the Debt Guarantee Program (DGP), which was part of the Federal Deposit Insurance Corporation's (FDIC) Term Liquidity Guarantee Program (TLGP), is also included. Finally, we merge data on shorter-term borrowing from the Federal Reserve's Term Auction Facility (TAF) and the term borrowing from the Discount Window (TDW) that was introduced

\footnotetext{
${ }^{4}$ For instance, see the debate between the Federal Reserve and Bloomberg News over the amount of funding provided through discount window loans, here: http://www.federalreserve.gov/generalinfo/foia/emergency-lendingfinancial-crisis-20111206.pdf
} 
by the Federal Reserve during the crisis to supplement the usual overnight lending associated with the lender-of-last-resort function.

This exercise highlights several facts that are often overlooked. For instance, after the CPP and DGP were made operational, usage of the Federal Reserve's TAF and TDW programs quickly abated, keeping the overall size of government support to banks roughly constant. In addition, the DGP provided more peak funding than the much more controversial and more frequently studied CPP, and so may have been an equally or even more important source of support for bank stability and lending.

To date, empirical research has focused primarily on the CPP and the TAF, but no consensus as to their effect on lending has been reached. However, little research has been done on other programs, such as the FDIC's DGP. The lack of consensus in the existing literature and lack of research on some programs reflects, in part, the difficulty of devising an empirical strategy to disentangle potential endogeneity between the demand for bank loans, the supply of alternative private funding sources, and banks' willingness to access the external funds offered by the government. In order to control for endogeneity, we note that participation in these programs was controversial, and, at times, the public disapproval of banks that used the programs broke down according to customers' political affiliations. Therefore, following $\mathrm{Li}$ (2013), we use variations in the intensity of support for the two major U.S. political parties in the states where the bank is headquartered as an instrument for participation in the government funding programs.

As an alternative instrument in cross sectional regressions, we construct a dummy variable for banks whose equity is publicly traded. We believe that this is a predetermined variable and unrelated to loan demand during the crisis. Furthermore, legal restrictions caused a 
delay in the ability of some types of privately held banks to access the CPP, and by the time those legalities were resolved, the acute phase of the crisis had passed and the program had become unpopular. Thus, banks that were publicly traded were more likely to access government funding.

Using those instruments in separate two-stage least squares procedures for the five term funding programs, we find that loan growth at banks that used those programs was not significantly affected by participation in these programs. Statistical tests strongly suggest that the instruments are valid for total government support received and individually for the CPP program.

Two important caveats apply to these results. Governments provided extraordinary support not only to support lending, but also to prevent the widespread failure of otherwise solvent institutions, which has been shown to lead to a potentially deeper and more sustained crisis (Bernanke, 1983). Gaby and Walker (2011) argue that the TARP injections for the largest bank holding companies had such material benefits. Berger et al. (2016) and Aubuchon and Wheelock (2010) also show that banks that received TARP injections were less likely to fail than those that did not, though they do not attribute causality. Jordan et al. (2011) show that a low market-to-book ratio was a strong predictor of banks that received TARP funds. The analysis in this paper does not account for that stabilizing effect, in that it looks only at the growth of loans conditional on a bank being in operation rather than the counterfactual of how many loans would not have been extended had numerous otherwise healthy banks failed (Veronesi and Zingales, 2010). Moreover, measuring the effect of TAF on total U.S. lending is complicated by the significant fraction of TAF funding that was extended to U.S. branches and agencies of foreign banks, which are important lenders to U.S.-based businesses, but data 
limitations restrict the analysis of the TAF program to its effect on lending by domestic commercial banks. $^{5}$

\section{Literature Review}

Authors who have studied the effects of crisis lending programs have largely used four strategies to identify their effects. Studies relying on macroeconomic and financial time series have largely implemented vector autoregression (VAR) models with identification assumptions implicit in the ordering of the variables in the VAR. Some studies using time series as well as some using microeconomic data have argued that the onset of the financial crisis itself can be used as an event study, with conditions prior to the crisis predetermined and therefore a valid control mechanism. Other microeconomic studies have used bank structure, such as differences across banks within the same holding company. And finally, researchers have tried to identify instrumental variables for the take-up of government assistance, with most such papers to date using variables related to political preferences. This section reviews the results obtained using those strategies in more detail.

A number of papers investigate which characteristics of banks most affected their lending during the crisis, without specifically addressing their use of government programs. Cornett et al. (2011) found that banks entering the crisis with more liquid balance sheets and higher capital ratios sustained lending better than other banks, and also point to off-balance sheet risks as important constraints on lending during the crisis period. Ivashina and Sharfstein (2010) found that banks with better access to deposit funding cut their lending less.

\footnotetext{
${ }^{5}$ U.S. branches and agencies of foreign banks lend hundreds of billions of dollars to firms in the United States, but generally do not make loans to U.S. households and hold a tiny fraction of commercial real estate loans.
} 
The majority of the literature in the early stages of the crisis focused on the impacts of non-standard policy measures on bank funding markets rather than on bank loans, and were inconclusive. ${ }^{6}$ Carpenter et al. (2014) carry the previous literature one step further by providing a link between non-standard measures, bank funding markets, and bank loans. They find that non-standard measures reduced liquidity risk in the US and the Euro Area and that the reduction in this stress stimulated bank loans. However, the direct impact of capital injections on bank loans was only significant in the Euro Area. Berrospide and Edge (2010) find, in a VAR framework, that adding capital equal to the size of CPP injections would be associated with a material increase in bank loans.

A growing number of papers look specifically at the effects of TARP and TAF on bank lending. Taliaferro (2009) observed that banks that received TARP used the bulk of the investment to shore up their regulatory capital ratios and subsequently expanded lending only \$1.04 for every dollar of CPP investment. Li (2013) instruments for TARP participation using four variables based on political and regulatory influence and finds that the program increased credit supply $\$ 404$ billion. A large amount of additional lending is also consistent with Berger and Raluca (2016b), who find substantial real effects for "main street" - increased employment

\footnotetext{
${ }^{6}$ Taylor and Williams (2009) do not find robust evidence that the TAF had a significant effect on term spreads in bank funding markets in late 2007 and early 2008, instead pointing to elevated levels of counterparty risk and expectations of future policy action. Thornton (2009) suggests that the TAF may not have affected spreads prior to September 2008, because the Fed had been offsetting extensions of credit under the TAF to keep the monetary base relatively constant. Thornton (2011) finds that the announcement of TAF signaled that conditions were worse than previously thought and so increased risk premiums in bank funding markets. In contrast, McAndrews et al. (2008), Christensen et al. (2009), and Wu (2008) find that TAF is associated with significant reductions in the Libor-OIS spread.
} 
and decreased bankruptcies — from the injection of capital into the banking sector. Puddu and Wächli (2013) show that banks receiving TARP funds increased their small business lending by exploiting differences between well-capitalized and under-capitalized banks within the same holding company. In contrast, Duchin and Sosyura (2012) find no significant impact of TARP on lending despite using one of the same instruments for TARP — whether the bank was in a district represented by a member of congress on a banking oversight committee - that was used by Li (2013). Berger et al. (2012a) use whether a bank had pledged collateral to the Federal Reserve's discount window prior to the crisis as an instrumental variable for the bank's use of TAF and find that banks receiving TAF had slower growth of some types of loans.

Another strand of literature focuses on how the non-standard measures affected risk taking by banks. Puddu and Wächli (2012) use an instrumental variables approach relying on balance-sheet composition prior to the financial crisis to conclude that banks that received TAF reduced their liquidity risk going forward. Asking a similar question but this time for a different facility, Black and Hazelwood (2013) find that the self-reported riskiness of new loan originations increased at large banks that received CPP injections while the same measure decreased at small banks that received funds from the CPP. Duchin and Sosyusa (2014), using the same instrumental variable as in their 2012 paper, also find that banks receiving TARP funds increased the riskiness of their loans, and did so in ways that did not affect measured risk-weighted assets, thus boosting their capital ratios despite taking more risk. Harris et al. (2013) document lesser gains in measures of bank efficiency at banks that received TARP funds than in banks that did not, attributing the cause to TARP funds lessening a sense of urgency to cut costs and strengthen balance sheets. 
Three papers make clear that controlling for the timing of repayment of TARP funds can be important influence on the results, something that the panel framework used in our paper can address and that a cross section approach like in Li (2013) would abstract from.

Bayazitova and Shivdasani (2012) investigated the decisions of banks to participate in CPP, the Treasury's approval decision of CPP applications, the banks' decisions to reject CPP injections, exit from CPP, and the impact of CPP on banks' valuation gains, capital ratios and asset quality. Cornett et al. (2013) document the initial characteristics of banks that received TARP and their effect on subsequent financial performance and timing of repayment of the TARP investment. Under the assumption that a difference-in-difference framework for TARP recipients compared before and after the bailout is an identified strategy, Berger and Raluca (2015) find that banks who received TARP funds and repaid them early gained market share over other banks, possibly due to the increased safety associated with the higher capital levels.

\section{Comprehensive Government Support Database}

As described briefly above and in more detail in the appendix, one of the purposes of this paper is to introduce a new comprehensive database that merges publicly available information about the usage of five key government support programs introduced between 2007 and 2010. Two programs, the TDW facility and the TAF, provided liquidity support to sound institutions for relatively short periods of time, usually less than 90 days. The CPP and the SBLF provided preferred stock at subsidized dividend rates for up to three years (and the option to extend the investment at closer to market rates) and the DGP guaranteed new longand short-term debt issuance for up to three years. Both the CPP and DGP provided subsidized long-term funding in an effort to calm the widespread concerns about the viability of individual 
institutions and reduce the need for them to shrink or restructure their balance sheets to become more liquid. The SBLF, introduced in the fourth quarter of 2010 as an expansion of, and potentially a substitute for, the CPP, also had a primary goal of boosting lending to small businesses by providing subsidized funding.

Combining these five programs into one database allows for the establishment, or at least reinforcement, of some stylized facts about the size of the programs and the way in which they interacted. Perusing the five panels of figure 3 and the columns of Table 1, one notices that even after controlling for the rollover of some debt issuance, the peak amount guaranteed by the more-under-the-radar DGP was 33 percent larger than the amount that was injected through the CPP. Another feature of the DGP was that over the entire period of its operation, almost all of its beneficiaries were large banks, those with more than $\$ 20$ billion in assets. In contrast, the largest banks aggressively repaid their CPP funds beginning in the second half of 2009 , and by the end of 2010, the majority of the remaining beneficiaries of the CPP program were mid-size and smaller institutions.

\begin{tabular}{|c|c|c|c|c|c|}
\hline \multicolumn{6}{|c|}{ Table 1} \\
\hline Summary Statistics (millions of USD, rounded) & TDW & TAF & DGP & CPP & SBLF \\
\hline Dates of program operation & $8 / 20 / 2007-3 / 1 / 2010$ & $12 / 17 / 2007-12 / 14 / 2009$ & $10 / 14 / 2008-10 / 31 / 2009$ & $10 / 28 / 2008-12 / 29 / 2009$ & $6 / 21 / 2011-9 / 27 / 2011$ \\
\hline$\#$ of participants* $<=\$ 1 \mathrm{~B}$ & 279 & 157 & 37 & 537 & 247 \\
\hline \# of participants* between $\$ 1 \mathrm{~B}$ and $\$ 20 \mathrm{~B}$ & 66 & 85 & 32 & 195 & 37 \\
\hline \# of participants* $>\$ 20 \mathrm{~B}$ & 7 & 31 & 31 & 31 & 1 \\
\hline Total Financed** & 167,385 & 451,282 & 397,221 & 245,465 & 3,923 \\
\hline Cumulative repaid through December 31, 2012 & NA & NA & $\mathrm{NA}$ & 234,373 & 120 \\
\hline Cumulative written-off (where applicable) & $\mathrm{NA}$ & NA & $\mathrm{NA}$ & 3,881 & 0 \\
\hline Debt outstanding as of December 31, 2012 & 0 & 0 & 4 & 7,204 & 3,803 \\
\hline \multicolumn{6}{|l|}{ Individual Observations*** } \\
\hline $\operatorname{Max}$ & 37,000 & 78,000 & 75,289 & 45,000 & 141 \\
\hline Mean & 264 & 1,038 & 4,490 & 134 & 14 \\
\hline Median & 10 & 50 & 75 & 10 & 9 \\
\hline \multicolumn{6}{|c|}{$\begin{array}{l}\text { Footnotes: } \\
\text { * "Participants" refers to the number of unique top holders with a positive balance in at least } 1 \text { quarter. } \\
\text { *** "Total financed" for the TAF and TDW programs represents the sum of each unique top holder's maximum daily balance. For the DGP, this represents the sum of each unique top holder's } \\
\text { *** Includes only non-zero quarterly observations of variables as of the last day in each quarter. }\end{array}$} \\
\hline
\end{tabular}


Figure 3:

Government Assistance Program Outstandings, by Financial Institution Size Coverage of CPP funds

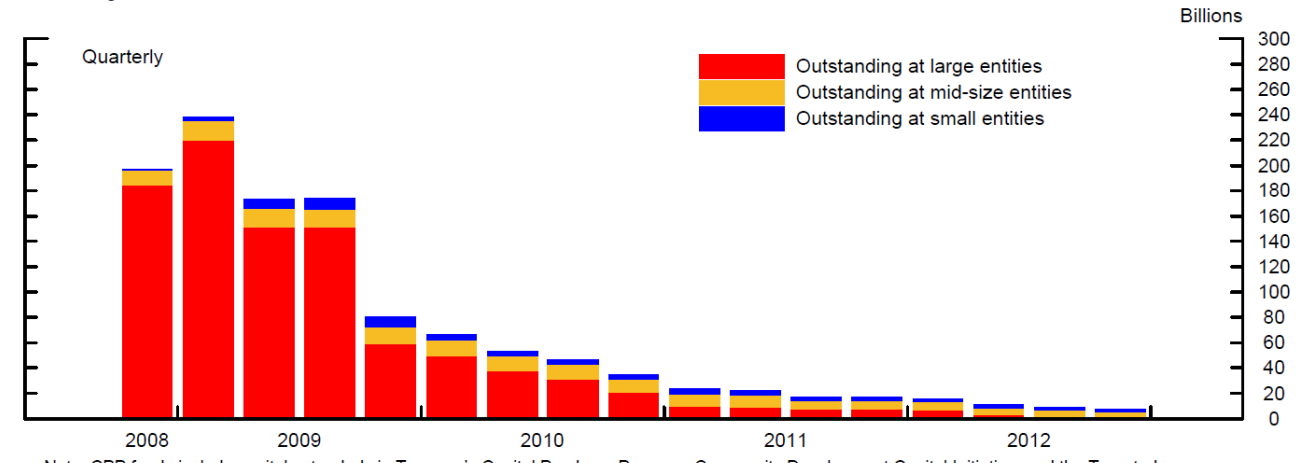

Note: CPP funds include capital extended via Treasury's Capital Purchase Program, Community Development Capital Initiative, and the Targeted Investment Program.

Coverage of DGP liabilities

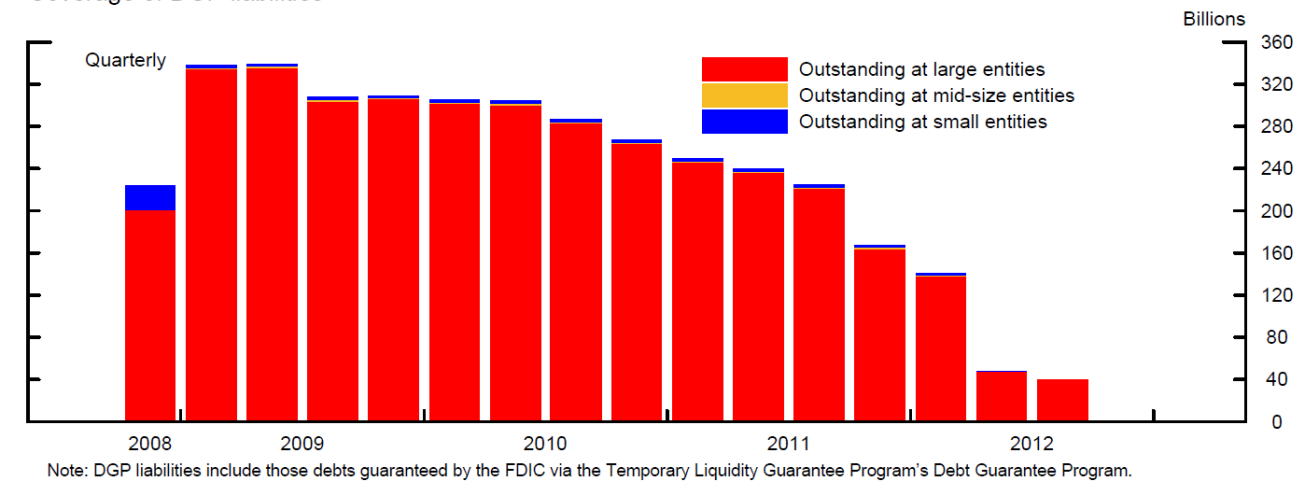

Coverage of SBLF liabilities

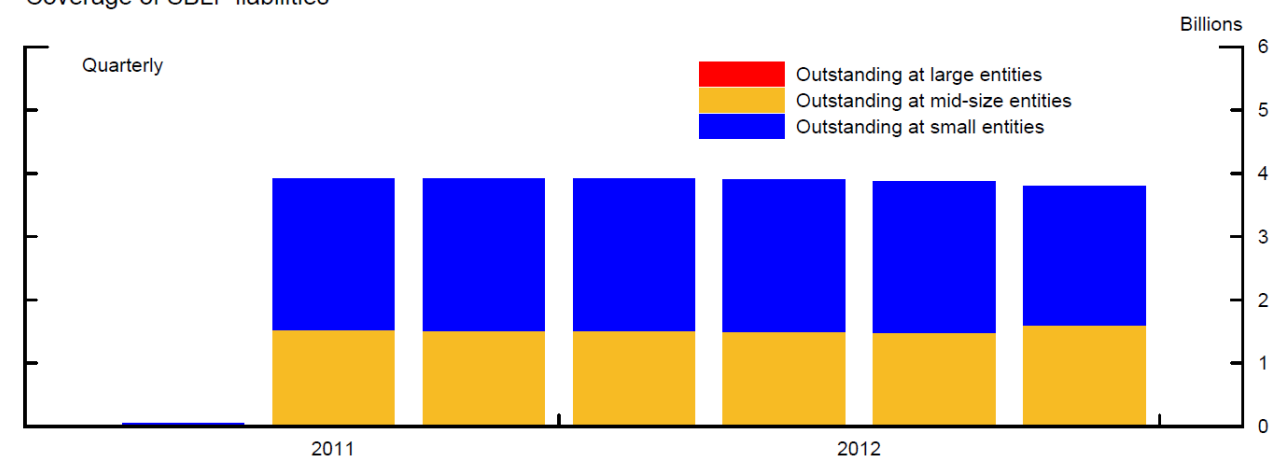

Note: SBLF liabilities include those funds extended to community banks via the Small Business Lending Fund, administerd by the U.S. Treasury.

Note: Large entities consist of those whose assets exceed $\$ 20$ billion. Mid-size entities have assets ranging between $\$ 1$ billion and $\$ 20$ billion. Small entities are those with assets less than $\$ 1$ billion. 
Figure 3 (continued):

Government Assistance Program Outstandings, by Financial Institution Size Coverage of term discount window liabilities

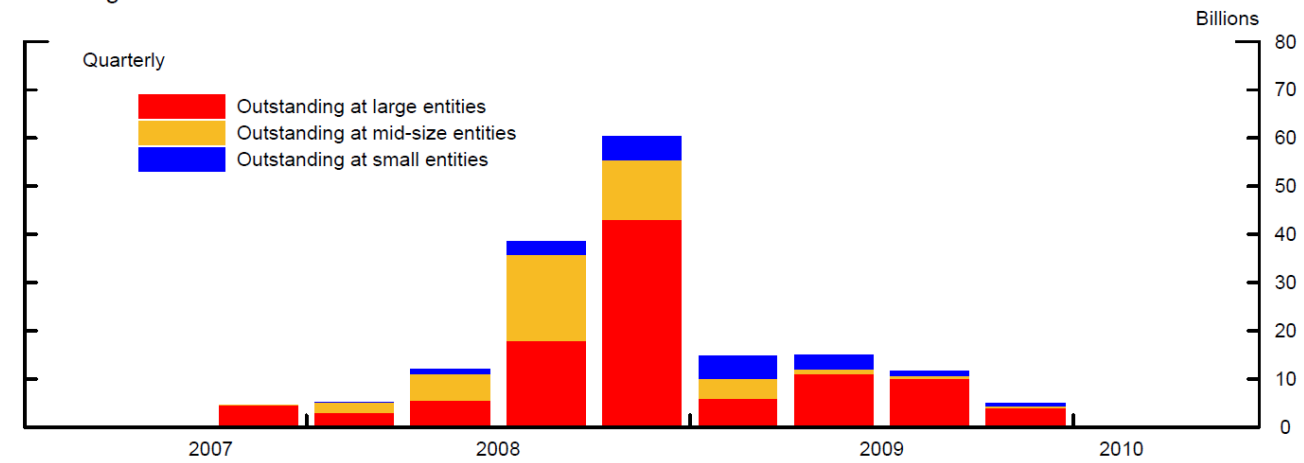

Note: Term discount window liabilities include term primary credit borrowings from the Federal Reserve discount window during the financial crisis.

Coverage of term auction facilities

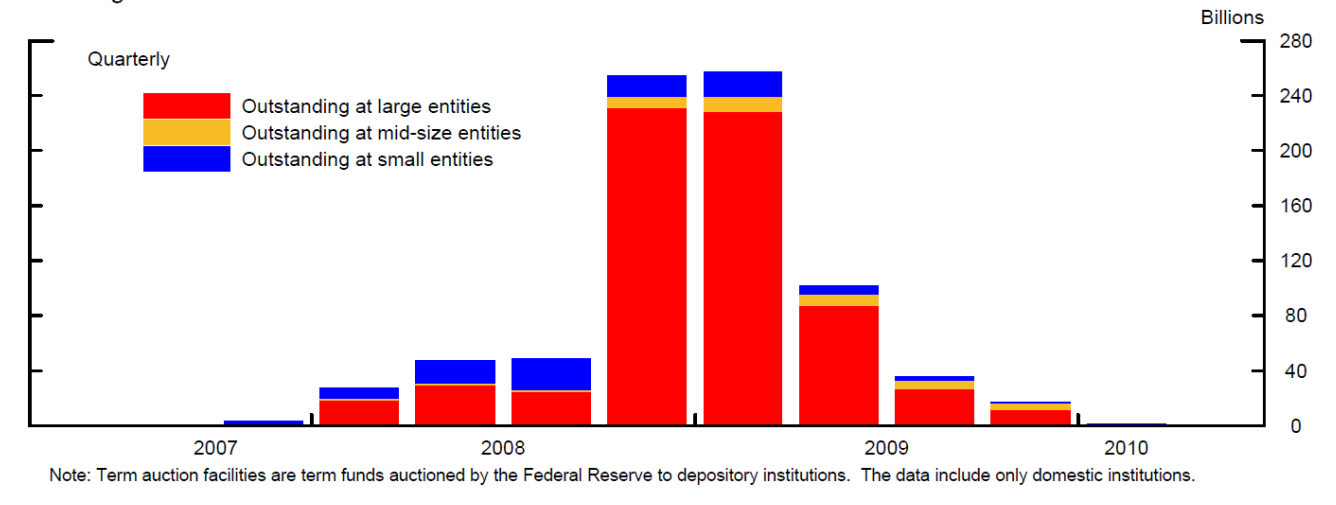

Demand for TAF from U.S. chartered BHCs, also adjusted to account for repeated rollovers of short-term financing, was about the same order of magnitude as the CPP at their respective peaks. Demand for this program also seemed to dry up quickly once the CPP and DGP were made available, suggesting that most banks preferred the longer-term funding to the TAF, even though CPP and DGP were somewhat more expensive. Though much smaller in size than the TAF and demanded more by smaller banks, the TDW option also shrank precipitously as soon as other sources of funds were offered.

As a result of the apparent substitution of CPP and DGP for TAF and TDW funds, the total amount of extraordinary government support for banks peaked in the first half of 2009 before falling quickly to about half the peak in 2010 and 2011 (figure 4). Likewise, banks 
often had both the DGP and CPP outstanding and some may have repaid CPP injections more quickly because they had access to long-term funding through the DGP. Later, most of the small and mid-size banks that participated in the SBLF took advantage of the opportunity to repay their outstanding CPP balances with SBLF funds. Thus, a focus solely on the effects of any single program will suffer from measurement error, as the many programs in operation simultaneously from late 2008 through 2012 were designed for similar purposes.

Figure 4:

Government Assistance Outstandings, by Program Type

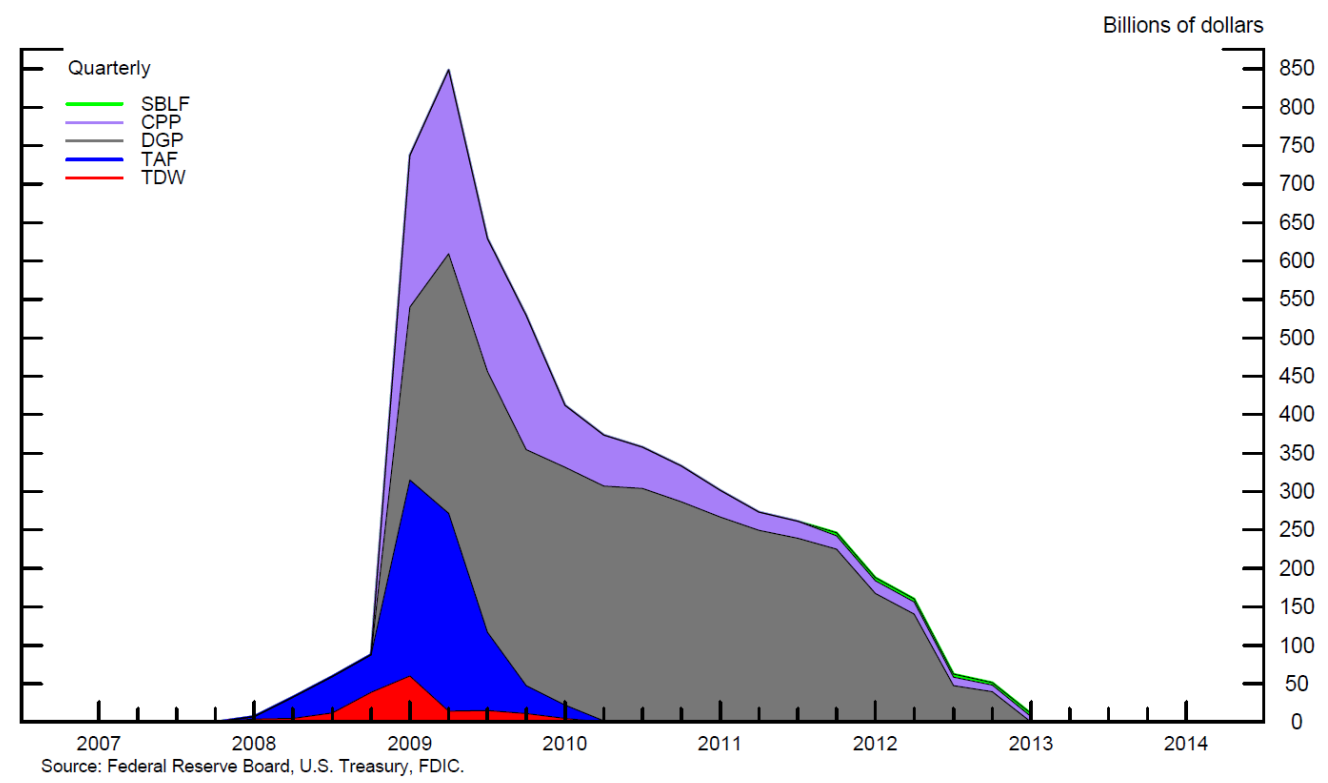

Note: TDW represents Term Discount Window lending, TAF represents the Term Auction Facility, CPP represents the sum of capital injected under the Capital Purchase Program, Targeted Investment Program, and Community Development Capital Initiative, DGP represents the Debt Guarantee Program of the Temporary Liquidity Guarantee Program, and SBLF represents the Small Business Lending Fund.

As shown by the top panel of figure 5, the correlation between usage of the CPP and usage of the DGP was between 0.5 percent and 0.8 percent in 2009 and 2010, reflecting the outstanding balances of both at large banks. But, those large banks did not refinance their DGP issuance into nonguaranteed debt the way they aggressively paid down CPP, and the correlation fell to zero in 2011 and 2012. Similarly, the correlation between the TAF and the DGP tells the 
story of the substitution in the usage of those two programs. The high correlation in the first half of 2009 shows that banks were using both initially, but then dropped TAF as the longerterm funding was locked in.

Figure 5:

Correlations of Financial Institutions' Participation in Government Assistance Programs
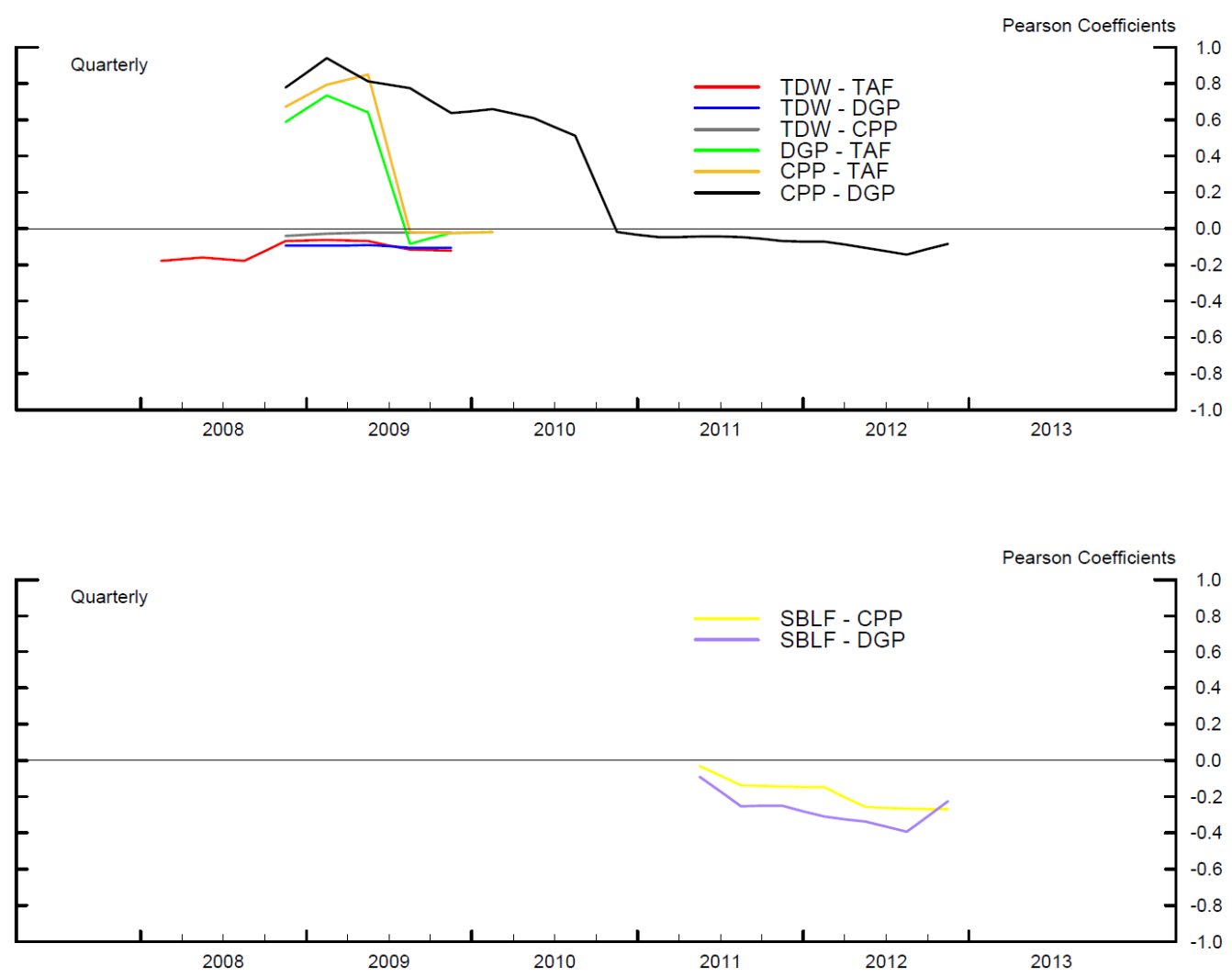

Note: TDW represents Term Discount Window lending, TAF represents the Term Auction Facility, CPP represents the sum of capital injected under the Capital Purchase Program, Targeted Investment Program, and Community Development Capital Initiative, DGP represents the Debt Guarantee Program of the Temporary Liquidity Guarantee Program, and SBLF represents the Small Business Lending Fund.

The substitution between government support programs illustrates one aspect of the endogeneity between loan demand, loan supply, and alternative funding sources. Figure 6 shows the difficulty of discerning the effect of the programs using the unconditional rates of loan growth, by participation and bank size. The vertical lines correspond to the periods during which the particular facility was open for new originations. For instance, large banks that were participants in the DGP (bottom panel, dotted black line) had consistently slower growth of 
loans over the 2009 to 2012 period than large banks that were not participants in that program (dotted blue line). Only the SBLF, which had a provision that reduced the cost of funding if banks increased their lending above a baseline, shows an unconditional rate of growth that is higher at participants than nonparticipants.

Figure 6:

Comparing Loan Growth Rates

Growth Rate of Loans: Term Discount Window Program

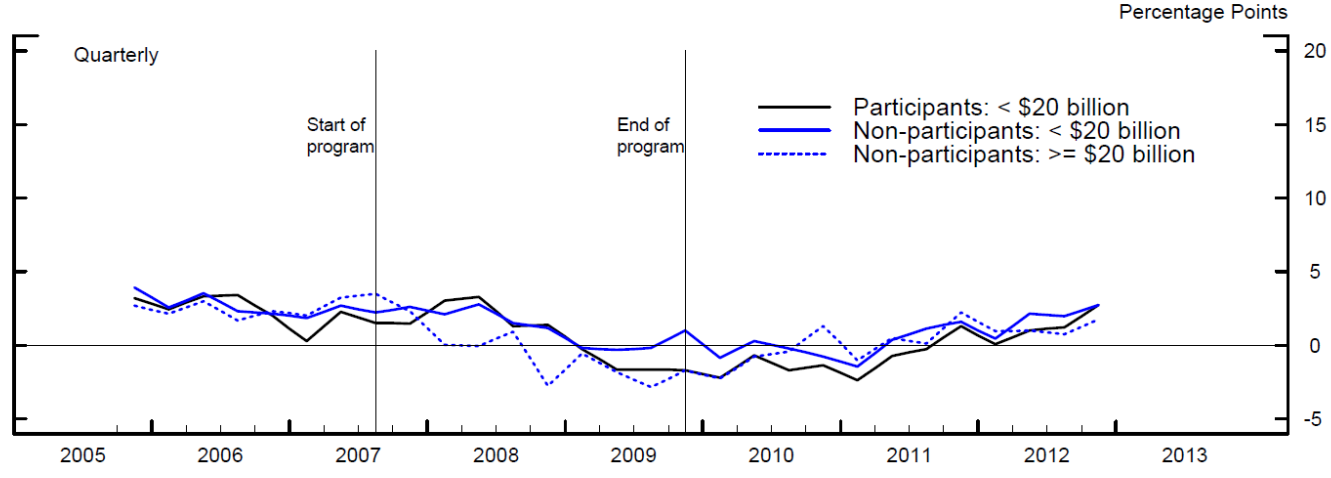

Growth Rate of Loans: Term Auction Facilities

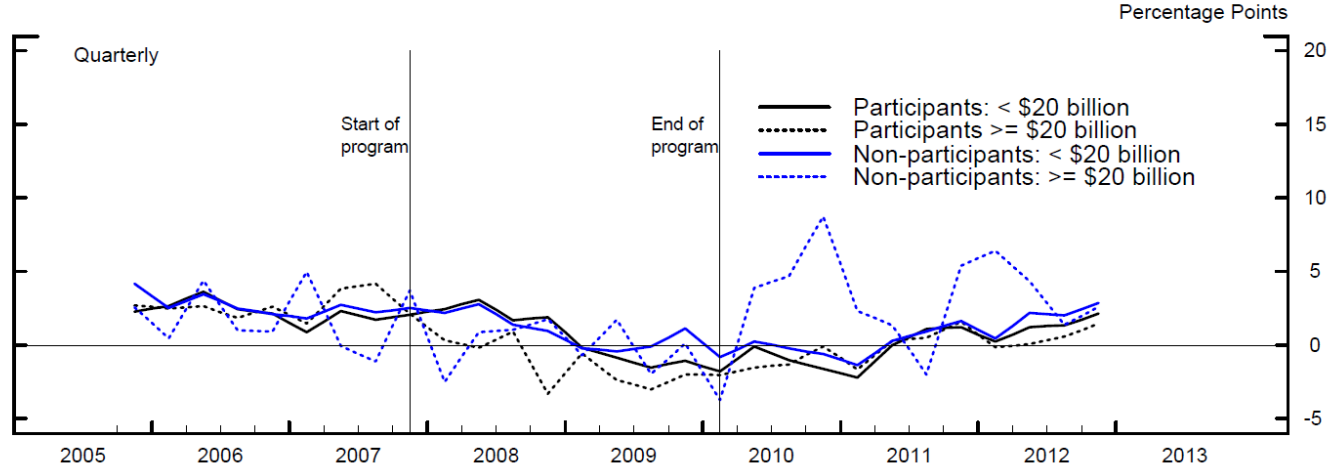

Growth Rate of Loans: Debt Guarantee Program

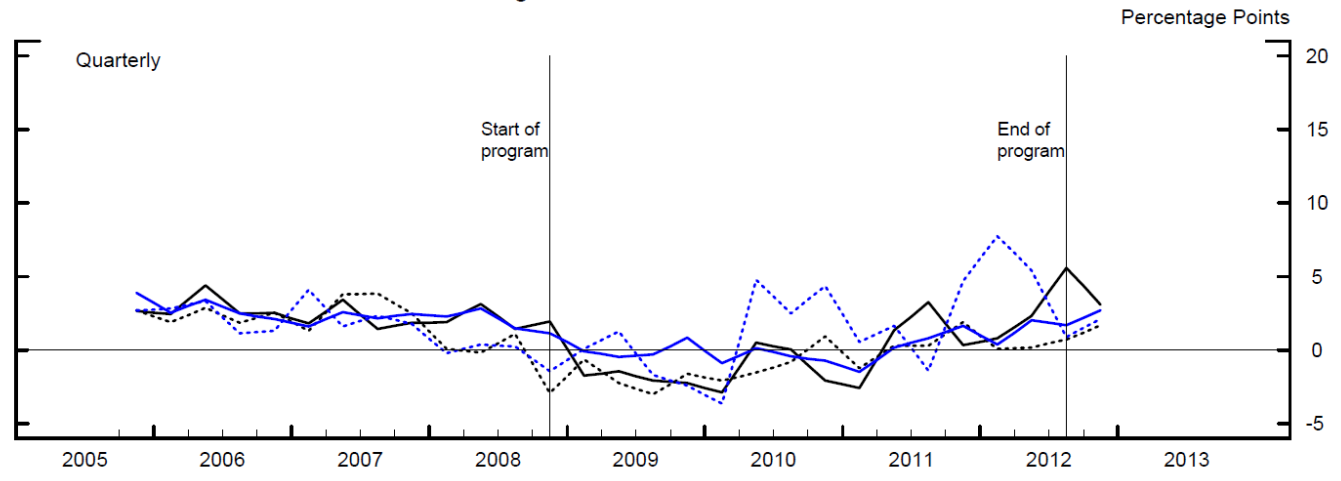




\section{Empirical Strategy}

When bank funding markets are functioning normally, the growth rate of bank loans should depend primarily on loan demand and the appetite for risk of the bank management. For a well-capitalized bank, growth likely would not be constrained in the near-term by the need to issue new equity, and funding for a new loan at prevailing interest rates would usually be available. As argued in Carpenter and Demiralp (2012), a generally accepted tenet of bank liability management is that the marginal sources of funding are short- and intermediate-term managed liabilities, which allow banks to lock in funding for a specified term in consideration of the maturity of their assets and the stability of their other sources of funding. ${ }^{7}$

During the crisis, however, borrowing costs skyrocketed — even for healthy institutions. As financial institutions hoarded liquidity, the supply of managed liabilities, particularly at tenors of longer than a few days, dried up. In large part, that panic was the result of lenders in interbank markets being unable to discern whether their potential counterparty remained solvent, and eventually the dysfunction proved too endemic to be solved by short-term liquidity programs, such as the TDW and TAF. That situation prompted additional government intervention to alleviate solvency concerns through programs like the CPP and the DGP. The SBLF, introduced subsequently to those programs partly in response to criticism that not enough had been done to help "main street," also was described by policymakers as an attempt to increase loan supply.

The programs should have been supportive of loan growth by reducing the cost of funding (move along the demand curve) and by easing risk aversion (shift the supply curve out).

\footnotetext{
${ }^{7}$ Managed liabilities are defined in this paper as large time deposits, federal funds purchased, repurchase agreements, and federal home loan bank advances
} 
However, in the aftermath of the financial crisis, demand for loans from the nonfinancial sector had dropped precipitously, and so the equilibrium quantity of loans may have declined even in the presence of that support. Furthermore, to the extent that the dominant motivation of banks using the programs was to enhance safety and soundness, measuring the impact of government support programs solely through their impact on bank loans may underestimate their true effects in the economy.

In order to study the relationship between the growth of bank loans and usage of those external funding opportunities, we treat the sum of CPP, SBLF, DGP, TAF, and TDW, which we call "Total Government Support (TGS)", as an endogenous variable in a two-stage least squares framework:

$\Delta \log (\text { Loans })_{t}=T_{t}+B_{i}+\beta_{1} \times(T G S)_{i, t} / T A_{i, t-1}+\beta_{2} \times(\text { Managed Liabilitie } s)_{i, t-1} / T A_{i, t-1}$

$+\beta_{3} \times(\text { Core Deposits })_{i, t} / T A_{i, t-1}+\beta_{4} \times(\text { Leverage Ratio })_{i, t-1}+\beta_{5} \times(\text { REcommit })_{i, t-1} /(\text { Commit }+T A)_{i, t-1}$

$+\beta_{6} \times(\text { Othcommit })_{i, t-1} /(\text { Commit }+T A)_{i, t-1}+\beta_{7} \times(\text { Illiquid Assets })_{i, t-1} / T A_{i, t-1}$

$+\beta_{8} \times(\text { RiskyRE })_{i, t-1} / A_{i, t-1}+\beta_{9} \times(\text { Delinquency ratio })_{i, t-1}+\beta_{10} \times$ Net chargeoff rate ${ }_{i, t-1}$

$+\beta_{11} \times \log \left(\right.$ Assets $\left._{i, t-1}\right)+\beta_{12} \times\left(\right.$ Employment Growth $_{i, t-1}+\beta_{13} \times\left(\right.$ Housing $_{i, t-1}+\varepsilon_{i t}$

In this equation, $i$ indexes banks, $t$ indexes quarters, $B_{i}$ are bank-specific fixed effects, and $T_{t}$ are quarterly time fixed effects. The errors, $\varepsilon_{i, t}$, are clustered at the bank level. Unless otherwise noted, balance sheet variables are normalized by the merger-adjusted total assets at the beginning of each quarter $T A_{i, t-1} \cdot{ }^{8}$ We use the sum of the average daily outstanding for each of the five government support programs in a given quarter rather than the quarter-end values (which is the

\footnotetext{
${ }^{8}$ The data are adjusted for mergers within a given period. For banks not involved in a merger, beginning-of-period balance sheet quantities are defined as the prior period quarter-end value. For banks involved in a merger, beginning-of-period values equal the sum of the prior period quarter-end values of the balance sheet item across the merging banks.
} 
convention of the Call Report data) because even if a bank pays back its funding in the last month or last day of a quarter, any amount of funding in the previous months may have importantly supported lending. ${ }^{9}$

Going over the components of TGS, TAF and TDW borrowing is expected to be a close substitute for ML and affect bank loans in the same way as ML. That is, we expect an increase in TAF in a particular quarter to fund an expansion of bank loans in the same quarter. Capital typically is viewed as a long-term and stable source of funding that does not vary significantly with short-term changes in loan-demand, and increases in capital generally improve not only a bank's lending capacity directly but also its access to other funding markets. Therefore, we expect CPP funding to have an impact over the duration of the period for which the bank benefits from a higher level of capital rather than just in the quarters in which there was a change in CPP investments. To reflect this belief, the CPP variable enters as a step function, which changes when there is a change in the value of CPP and stays at that level until there is another change, usually from a bank's decision to repay the Treasury. This way, the cumulative borrowing from the CPP has an impact on bank loans for as long as the bank holds the investment rather than expecting only a relatively immediate impact of CPP investments and redemptions on bank loans. The same rationale and process is used to construct the variables for the DGP and SBLF. However, funding through the government support programs could also be used to purchase securities or to pay down more expensive liabilities and support profits while keeping the size of the balance sheet roughly constant. In that case, those programs may not necessarily be a significant factor in the loan equation. In fact, if banks that took government support were

\footnotetext{
${ }^{9}$ As a robustness check, we have considered adding the lagged TAF borrowing to the specification but it was not significant in affecting bank loans. The results from this exercise are not shown in the empirical analysis below.
} 
driven by risk aversion or "animal spirits", a spurious negative relationship between government support and bank loans might arise.

\subsection{Instruments for the TGS}

The main problem in any instrumental variables (IV) estimation is the difficulty of finding valid instruments. As described above, several authors have found that variables controlling for political relationships or party affiliation affect demand for the CCP. The TARP legislation was highly controversial and unpopular across the political spectrum in America, and many bankers believe that they benefitted by advertising that they were not participating. ${ }^{10}$ Evidence also suggests that the "bailout program" was one of the key factors in the organization of the "TEA (Taxed Enough Already) Party" movement, a loose collection of groups across the country that began to organize in the spring of 2009 and whose self-identified members have tended to vote disproportionately for Republican Party candidates (Madestam et al., 2013). Many sources also report that the TEA Party movement was further strengthened by the passage of the package of health insurance changes known as the Affordable Care Act later that year, a development unrelated to supply of, or demand for, bank loans. The Republican Party gained control of the U.S. House of Representatives in the November 2010 elections, more than reversing gains made by the Democratic Party in 2008. The Republican Party also took control of several state legislatures and governorships that year, which in many cases were able to redefine congressional districts that helped the party retain control of the House of

\footnotetext{
${ }^{10}$ For instance, see LaMonica Paul R, "The bankers who said 'hell no' to bailouts" at http://money.cnn.com/2010/09/15/news/companies/thebuzz/index.htm
} 
Representatives in the 2012 elections despite the reelection of a Democratic president, Barack Obama.

Thus, banks whose business is concentrated in areas where the Republican Party has strong support may have been less likely to accept capital injections from the TARP-related CPP in 2009 than banks in areas where the Democratic Party was dominant, regardless of their financial condition or prevailing loan demand. Moreover, banks that witnessed the success of the TEA Party movement in their local markets during the 2010 election cycle may have repaid TARP investments more quickly than planned and more quickly than banks in other areas, again irrespective of existing trends in loan demand. Thus, we propose that the intensity of support for political parties in banks' home markets, and the change in that support over the crisis period, can be used as an instrumental variable for banks' likelihood of applying for CPP and the length of time that such investments were outstanding. Furthermore, given the intensity of the backlash against the CPP, bank owners and managers in such "red" states may also have shunned participation in other government programs, despite their lower profile.

An observable measure of intensity of support for the Democratic Party in the banks' local markets is the number Democrats in each state's delegation to the House of Representatives from 2007 to 2012. ${ }^{11}$ That measure can be transformed into a bank-specific variable by matching the data to the state where the bank is headquartered. This variable is heretofore

\footnotetext{
${ }^{11}$ Given the two-party system in the United States, mapping the seats held by the Democratic Party is a sufficient statistic and without loss of generality. The data on party affiliation of congressional delegations was sourced from Wikipedia, December 12, 2013. http://en.wikipedia.org/wiki/Members_of_the_110th_United_States_Congress, http://en.wikipedia.org/wiki/Members_of_the_111th_United_States_Congress, http://en.wikipedia.org/wiki/Members_of the_112th_United_States_Congress.
} 
referred to as Hq_dseats. ${ }^{12}$ The total number of seats held by Democrats was chosen rather than a fraction of the total delegation in order to better account for diversity of political opinion in larger states, and because government intervention in the banking sector likely was more unpopular in less populous areas, which tend also to lean Republican in national elections.

Within each state, the number of seats in Congress held by members of the Democratic Party ranges from 0 to 35 , with a mean of 10 and standard deviation of 10 . As is widely understood, the numbers tend to be larger in the northeast and west coast than in the central plains and southeast.

\subsection{Variables treated as predetermined}

Control variables that act as proxies for overall and bank-specific loan demand are included directly in the estimation. The time fixed effects, $T_{t}$, absorb market-wide funding conditions and economy-wide demand conditions during each quarter. The time fixed effects are more likely to be effective controls for these key influences on loan growth for large banks operating in multiple markets. To better control for economic conditions in individual markets populated by smaller banks, we match state-level employment growth data from the Bureau of Labor Statistics and the state-level house price index from CoreLogic with the locations of the bank's branches. An increase in the employment growth in a bank's local markets is expected to

\footnotetext{
${ }^{12}$ The political dynamics of the location of the bank's headquarters are assumed to be the most influential among bank management. Results using a variable created by using all states where a bank operates branches and creating a branch-weighted average of the number of seats held by Democrats in states where the bank operates were not materially different.
} 
decrease both loan supply and loan demand such that $\beta_{12}>0$. Similarly, improvements in the housing price index (weighted by branch locations) is expected to promote loan growth: $\beta_{13}>0$.

Most of the remaining right-hand-side variables in Equation (1) are common controls for loan supply from the works cited above. We use the lagged values of the explanatory variables in part to break the explicit balance sheet identity and argue that the predetermined quantity also aides identification, because balance sheet quantities are often difficult or costly for a bank to adjust in the short-term.

We control for the extent to which the bank relies on funding by core deposits, which are defined as transactions and savings deposits. ${ }^{13}$ A large fraction of core deposits are typically “sticky" because of customers' switching costs, and so banks use them to fund long-term investments, such as loans, even though they can technically be withdrawn immediately. A higher fraction of core deposits should be positively related to bank loans $\left(\beta_{3}>0\right)$ and negatively related to demand for other sources of funding.

The TCE ratio is defined as the ratio of a bank's tangible common equity capitalcommon stock and surplus plus retained earnings--to its total risk-weighted assets at the beginning of the quarter. ${ }^{14}$ Thus, the TCE ratio is not affected by the increase in preferred stock at banks that received CPP or SBLF funds. The TCE ratio was also reportedly the most commonly referenced indicator of capital strength by market participants during the crisis.

\footnotetext{
${ }^{13}$ Core deposits typically include small-denomination time deposits as well; however, the arguments presented to treat core deposit flows during the crisis period as plausibly exogenous cannot be sustained for time deposits.

14 The key results of the analysis are not sensitive to the choice of capital ratio. The alternatives considered were total capital/assets, deviations from a bank-specific target defined as a long-run moving average, or the minimum of deviations from the regulatory well-capitalized thresholds.
} 
Specifications that investigate the effect of the TAF or TDW funding on loan growth use the regulatory leverage ratio - tier 1 capital (which includes preferred stock) divided by average total tangible assets- to account for any effects of government capital injections.

The theoretical literature is divided on the impact of bank capital on bank loans. Some theories argue that bank capital might impede liquidity creation because it makes the bank's capital structure less fragile (see e.g. Diamond and Rajan, 2000). Others argue that higher capital improves the bank's ability to absorb risk and hence higher capital ratios allow banks to create more liquidity (see e.g. Coval and Thakor, 2005). Hence, we do not have priors about the sign of $\beta_{4}$ in the loan growth equation.

Off-balance-sheet exposures also importantly affect lending flows, but the effects are sometimes hard to determine ex ante (Cornett et al., 2011). Because the collapse of the real estate market in the U.S. was a primary cause of the crisis, unused commitments have been split into REcommit, commitments to fund residential or commercial real estate loans, and Othcommit, which refers to unused commitments to fund other types of loans. On the one hand, banks with greater unused commitments are exposed to liquidity risk, which may prompt an increase in their liquid assets and reduce loans $\left(\beta_{5}<0, \beta_{6}<0\right)$. On the other hand, banks are unable to cancel some types of unused commitments, and the heightened demand for liquidity by customers at the beginning of a period of economic stress can generate loan growth against those previously existing commitments $\left(\beta_{5}>0, \beta_{6}>0\right)$.

The composition of assets also influences prospective lending capacity. Illiquid Assets are defined as the sum of total loans and leases with a maturity of more than one year, as well as structured financial products, asset-backed securities (including mortgages) that were not issued or guaranteed by federal government agencies, fixed assets, intangible assets, investments in 
subsidiaries, and total other assets defined on schedule RC-F of the Call Reports. In addition, the regressions include a separate control for a subset of these assets: the amount of relatively higher-risk real estate assets held by the bank, RiskyRE. This variable includes private MBS, CMBS, adjustable rate residential mortgages, residential junior liens and home equity loans, mortgage servicing assets, and other real estate owned. Banks holding a large share of illiquid assets or riskier mortgage products are expected to have slower loan growth $\left(\beta_{7}<0, \beta_{8}<0\right)$.

Poor loan performance may reflect strains among the bank's customer base that would reduce loan demand and prompt the bank to substitute away from loans and toward safer and more liquid assets, in part by shrinking their balance sheet to improve capital adequacy. The controls for these factors are delinquent loans divided by previous period tier 1 common equity (Delinquency ratio) and the net loss rate - gross charge-offs of loans during the period divided by delinquent loans at the beginning of the period. Both variables are needed because loss rates on delinquent loans can be quite different across loan categories, so either one in isolation could be misleading. We expect $\beta_{9}<0$, and $\beta_{10}<0$ as well.

\subsection{Description of sample and data}

The sample used in the paper includes bank holding companies that are included in the Y-9C Report. The sample period extends from 2007:Q2, when TDW loans first became available, until 2012:Q4, two years after the implementation of the SBLF. No new CPP funds were disbursed after 2009:Q3, but CPP funds were still being held by some banks and repaid by others through 2012:Q4, but no bank with more than $\$ 1$ billion in total assets had outstanding CPP funds at that time. The sample has 9034 observations and 499 distinct commercial banks. Table 2 displays summary statistics for the variables used in the analysis. 
Table 2: Descriptive Statistics of the Variables used in the Empirical Analysis

\begin{tabular}{|c|c|c|c|c|c|}
\hline Description & $\begin{array}{l}\text { Number } \\
\text { of obs. }\end{array}$ & Mean & $\begin{array}{l}\text { Std. } \\
\text { Dev. }\end{array}$ & Min & Max \\
\hline 1. $\quad(T G S)_{\mathrm{i}, \mathrm{t}} /$ Assets $_{\mathrm{i} . \mathrm{t}-1}$ & 9034 & 0.67 & 1.34 & 0.00 & 18.16 \\
\hline 2. Loan Growth L $_{i, \mathrm{t}}$ & 9034 & 0.87 & 5.04 & -45.54 & 73.18 \\
\hline 3. $\quad\left(\right.$ Managed Liabilitie $\left.s_{i . t-1}\right) /(\text { Assets })_{i, t-1}$ & 9034 & 16.96 & 9.29 & 0.00 & 86.34 \\
\hline 4. $\quad\left(\right.$ Core Deposits $\left.{ }_{i, t-1}\right) /(\text { Assets })_{i, t-1}$ & 9034 & 38.56 & 12.83 & 0.00 & 81.38 \\
\hline 5. TCE Ratio $i, t-1$ & 9034 & 10.13 & 5.35 & -18.51 & 106.60 \\
\hline 6. REcommit Ratio $, t,-1$ & 9034 & 5.50 & 3.66 & 0.00 & 30.97 \\
\hline 7. Other Commit Ratio $i, t-1$ & 9034 & 9.81 & 9.61 & 0.00 & 89.65 \\
\hline 8. $\quad(\text { Illiquid Assets })_{i, t-1} /(\text { Assets })_{i, t-1}$ & 9034 & 56.35 & 12.27 & 5.06 & 95.14 \\
\hline 9. $\quad(\text { RiskyRE })_{i, t-1} /(\text { Assets })_{i, t-1}$ & 9034 & 18.76 & 9.56 & 0.00 & 73.00 \\
\hline 10. $\quad(\text { Delinquencies })_{i, t-1} /(\text { Tier } 1 \text { Common })_{i, t-1}$ & 9034 & 43.49 & 158.07 & -4010.45 & 4795.83 \\
\hline 11. (Net chargeoff rate $)_{i, t-1}$ & 9034 & 7.40 & 11.31 & -476.19 & 250.24 \\
\hline 12. $\log (\text { Assets })_{i, t-1}$ & 9034 & 15.08 & 1.38 & 12.24 & 21.59 \\
\hline 13. (Employment Growth $)_{i, t-1}$ & 9034 & 0.02 & 1.63 & -29.45 & 29.78 \\
\hline 14. (Housing $)_{i, t-1}$ & 9034 & -0.83 & 1.62 & -8.39 & 10.43 \\
\hline
\end{tabular}

The abbreviation RE stands for real estate.

\subsection{Panel Estimation and Results}

If the chosen instruments are relatively weak, then IV estimation becomes less precise and the standard errors can become many times larger compared with those from inconsistent OLS. Because of this potential complication and the moderate sample size, we use the GMM continuously updated estimator (CUE), which is reported to have superior finite sample performance (Hahn et al., 2004). ${ }^{15}$ As a result, our findings regarding the significance of a particular funding facility are expected to err on the conservative side.

Our panel has 22 quarters from the first distribution of government support in 2007:Q2 through the two-year anniversary of SBLF in 2012:Q4. On the one hand, that time series length raises the question of whether the dynamic panel regression will be sufficiently unbiased, as the

\footnotetext{
${ }^{15}$ We use user-developed xtivreg2 module in STATA (see Schaffer, 2010).
} 
bias converges to 0 at the rate $1 / \mathrm{T}$. On the other hand, that bias may be smaller than the loss of efficiency from use of an Arellano and Bond (1991) type of estimator with so many potential instruments. $^{16}$

\section{Table 3a: First Stage Regression}

Dependent variable: $(\mathrm{TGS})_{\mathrm{i}, \mathrm{t}} /$ Assets $_{\mathrm{i} . \mathrm{t}-1}$

\begin{tabular}{|c|c|c|}
\hline & & I.CUE \\
\hline 1. & $H q_{-}$dseats $_{i}$ (Instrument) & $\begin{array}{l}0.05 * * \\
(2.21)\end{array}$ \\
\hline 2. & Loan Growth $_{i, t-1}$ & $\begin{array}{l}0.00 \\
(0.80)\end{array}$ \\
\hline 3. & $\left(\right.$ Managed Liabilitie $\left.s_{i . t-1}\right) /(\text { Assets })_{i, t-1}$ & $\begin{array}{l}-0.02 * * \\
(-4.09)\end{array}$ \\
\hline 4. & $\left(\right.$ Core Deposits $\left._{i, t-1}\right) /\left(\right.$ Assets $_{i, t-1}$ & $\begin{array}{l}-0.02 * * \\
(-3.26)\end{array}$ \\
\hline 5. & TCE Ratio ${ }_{i, t-1}$ & $\begin{array}{l}-0.07 * * \\
(-5.31)\end{array}$ \\
\hline 6. & Recommit Ratio $_{i, t-1}$ & $\begin{array}{l}-0.05 * * \\
(-2.53)\end{array}$ \\
\hline 7. & Other Commit Ratio $i, t-1$ & $\begin{array}{l}-0.02 * * \\
(-1.98)\end{array}$ \\
\hline 8. & $(\text { Illiquid Assets })_{i, t-1} /(\text { Assets })_{i, t-1}$ & $\begin{array}{l}-0.01 \\
(-1.57)\end{array}$ \\
\hline 9. & $(\text { RiskyRE })_{i, t-1} /(\text { Assets })_{i, t-1}$ & $\begin{array}{l}-0.01 \\
(-0.56)\end{array}$ \\
\hline 10. & $(\text { Delinquencies })_{i, t-1} /(\text { Tier } 1 \text { Common })_{i, t-1}$ & $\begin{array}{l}0.00 \\
(0.60)\end{array}$ \\
\hline & $(\text { Net chargeoff rate })_{i, t-1}$ & $\begin{array}{l}0.004 * * \\
(3.47)\end{array}$ \\
\hline 12. & $\log (\text { Assets })_{i, t-1}$ & $\begin{array}{l}-0.50 * * \\
(-2.24)\end{array}$ \\
\hline
\end{tabular}

${ }^{16}$ Arellano-Bond (1991) estimator is designed for short panels with a wide cross section. In long panels, a shock to the country's fixed effect declines with time and the correlation of the lagged dependent variable with the error term becomes insignificant (Roodman, 2006). Judson and Owen (1999) use Monte-Carlo simulations and show that the so-called "Nickell bias" is no longer significant for panels where the time dimension is larger than 30. 


\begin{tabular}{ll|l} 
13. & (Employment Growth $)_{i, t-1}$ & 0.00 \\
& & $(0.15)$ \\
14. & (Housing $)_{i, t-1}$ & $-0.08^{* *}$ \\
& & $(-3.61)$ \\
15. & Bank dummies & Yes \\
16. & Quarterly time dummies & $\mathrm{Yes}$ \\
17. & F test of excluded instruments & Prob $>\mathrm{F}=0.03$ \\
\hline & & 462 \\
\hline 18. & Number of banks & 8198 \\
19. & Number of observations & 8.89 \\
\hline \hline t-ratios based on robust standard errors are reported in parenthesis under \\
coefficient estimates. $* * / *$ indicates significance at $95 / 90$ percent level of \\
confidence respectively. FE Model, errors clustered around banks.
\end{tabular}

Table 3a shows the first-stage regression where the five government support programs are aggregated together and the sum is treated endogenously. ${ }^{17}$ Starting with the performance of the instrument for the total amount accessed from TGS (row 1), the number of seats held by Democrats in the bank's home state's delegation to the U.S. House of Representatives is both statistically and economically significant in the first stage regression. A difference of 5 seats held by Democrats leads to a TGS investment that is about 0.30 percent of assets larger, compared with the average TGS of about 1 percent of assets. This is the expected relationship if banks in less populous states and Republican-leaning areas viewed participation in the TGS as a potential negative signal to their most likely customers. The F-test of excluded instruments is rejected, indicating that TGS is identified by the proposed instrument after partialing out the linear projection of other regressors. While the largest banks have nearly national footprints and

\footnotetext{
${ }^{17}$ Even though it seems plausible to use an indicator variable for borrowing from the TAF or receipt of TARP funds along with probit or logit estimation to generate first-stage predicted values, this is not necessary and can even cause more misspecification problems (Angrist and Krueger, 2001). Moreover, consistency of the second-stage estimates does not rely on using the right functional form for the first; estimates from a first-stage linear regression generate consistent second-stage estimates even if the endogenous variable is discrete or censored (Kelejian, 1971).
} 
so may not be heavily influenced by the dominant political affiliation of the jurisdictions in which they are headquartered, the results are robust if the sample is restricted to just those regional and community banks with assets less than $\$ 50$ billion.

Turning to the control variables, Banks with higher levels of core deposits or TCE ratio are less likely to have accessed the long-term funding programs at any point in the sample period, consistent with stronger banks declining participation in an unpopular program. Banks with more managed liabilities also were less likely to use government support programs, even though such funding became strained during the crisis. This result is consistent with the directive that such programs be made available only to banks that were fundamentally sound and thus more likely to have retained access to those funding markets. Banks that had higher chargeoff rates were more likely to obtain TGS and retain the funding through the end of the sample period. Lastly, because large banks face greater likelihood of being identified if they used significant discount window credit, the fixed overall size of the TAF program, and the practical reality that the size of the CPP program likewise limited the amount that could be allocated to the largest banks to less than the 3 percent of risk-weighted assets available to smaller banks, the negative coefficient on bank size is expected. Banks that have more loan commitments are less likely to obtain funding, which is somewhat difficult to explain unless banks that had more unused commitments were better situated going into the crisis. It is also important to note that house prices are very significant and negative in the first stage regression - banks that got TGS were in areas that were hit worst by the house price collapse. This adds credibility to the use of that variable as a demand indicator. 
Table 3b: Loan Growth Regression

\begin{tabular}{|c|c|c|c|}
\hline & & I.OLS & II.CUE \\
\hline 1. & $(T G S)_{i, \mathrm{t}} /(\text { Assets })_{i . t-1}$ & $\begin{array}{l}-0.02 \\
-0.36\end{array}$ & $\begin{array}{l}2.33 \\
1.09\end{array}$ \\
\hline 2. & Loan Growth $_{i, t-1}$ & $\begin{array}{l}0.003^{*} \\
1.83\end{array}$ & $\begin{array}{l}0.00 \\
1.07\end{array}$ \\
\hline 3. & 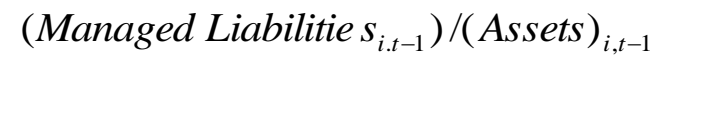 & $\begin{array}{l}0.04 * * \\
2.13\end{array}$ & $\begin{array}{l}0.10^{*} \\
1.77\end{array}$ \\
\hline 4. & $\left(\right.$ Core Deposits $\left._{i, t-1}\right) /\left(\right.$ Assets $_{i, t-1}$ & $\begin{array}{l}0.03^{*} \\
1.63\end{array}$ & $\begin{array}{l}0.07 * \\
1.65\end{array}$ \\
\hline 5. & TCE Ratio $o_{i, t-1}$ & $\begin{array}{l}0.19^{* *} \\
3.50\end{array}$ & \\
\hline 6. & REcommit Ratio $_{i, t-1}$ & $\begin{array}{l}0.53 * * \\
8.56\end{array}$ & $\begin{array}{l}0.63^{* *} \\
4.91\end{array}$ \\
\hline 7. & Other Commit Ratio $i, t-1$ & $\begin{array}{l}0.21 * * \\
4.27\end{array}$ & $\begin{array}{l}0.26^{* *} \\
3.13\end{array}$ \\
\hline 8. & $(\text { Illiquid Assets })_{i, t-1} /(\text { Assets })_{i, t-1}$ & $\begin{array}{l}-0.13 * * \\
-4.92\end{array}$ & $\begin{array}{l}-0.11^{* *} \\
-3.52\end{array}$ \\
\hline 9. & $(\text { RiskyRE })_{i, t-1} /(\text { Assets })_{i, t-1}$ & $\begin{array}{l}0.02 \\
0.43\end{array}$ & $\begin{array}{l}0.03 \\
0.69\end{array}$ \\
\hline 10. & $(\text { Delinquencies })_{i, t-1} /(\text { Tier } 1 \text { Common })_{i, t-1}$ & $\begin{array}{l}-0.001 * \\
-1.68\end{array}$ & $\begin{array}{l}-0.001^{*} \\
-1.66\end{array}$ \\
\hline 11. & $(\text { Net loss rate })_{i, t-1}$ & $\begin{array}{l}-0.02 * * \\
-2.21\end{array}$ & $\begin{array}{l}-0.03^{* *} \\
-2.34\end{array}$ \\
\hline 12. & $\log (\text { Assets })_{i, t-1}$ & $\begin{array}{l}-2.33 * * \\
-3.70\end{array}$ & $\begin{array}{l}-1.12 \\
-0.81\end{array}$ \\
\hline 13. & ${\text { (Employment Growth })_{i, t-1}}$ & $\begin{array}{l}0.12^{*} \\
1.65\end{array}$ & $\begin{array}{l}0.12 \\
1.38\end{array}$ \\
\hline 14. & $(\text { Housing })_{i, t-1}$ & $\begin{array}{l}0.09 \\
0.84\end{array}$ & $\begin{array}{l}0.27 \\
1.33\end{array}$ \\
\hline 15. & Bank dummies & Yes & Yes \\
\hline 16. & Quarterly time dummies & Yes & Yes \\
\hline 17. & $\begin{array}{l}\text { Underidentification test } \\
\text { (Kleibergen-Paap rk LM statistic) } \\
\text { Overidentification test of all instruments } \\
\text { (Hansen J statistic) }\end{array}$ & -- & $\begin{array}{l}\text { LM }=5.30 \\
\text { Chi-sq }(1) \\
\text { P-value=0.02 } \\
\text { Just- } \\
\text { identified }\end{array}$ \\
\hline $\begin{array}{l}19 . \\
20 .\end{array}$ & $\begin{array}{l}\text { Number of banks } \\
\text { Number of observations }\end{array}$ & $\begin{array}{l}475 \\
8232\end{array}$ & $\begin{array}{l}462 \\
8198\end{array}$ \\
\hline
\end{tabular}

t-ratios based on robust standard errors are reported in parenthesis under coefficient estimates in the first column and z-ratios based on robust standard errors are reported in the second column. ${ }^{* *} /{ }^{*}$ indicates significance at 95/90 percent level of confidence respectively. FE Model, errors clustered around banks. 
The second column in Table $3 \mathrm{~b}$ shows the results from the second stage where the growth rate of bank loans are regressed on the predicted values of the TGS variable along with the control variables. For comparison purposes, we also show the OLS estimation, which treats TGS as an exogenous variable, in the first column. Looking at the OLS results, the negative coefficient on the long-term funding variable (row 2) suggests that government funding is unrelated to growth in bank loans.

Balance sheet strength is an important determinant of loan growth. An increase in the TCE ratio associated with an increase the growth rate of bank loans, suggesting that banks with high book value of equity were more willing to absorb risk and generate more liquidity, as in Berger et al. (2012b). A higher ratio of illiquid assets was associated with slower growth in bank loans, consistent with Cornett et al., (2011), and suggesting that banks that start a particular quarter with less-liquid asset portfolios tend to improve their liquidity by issuing fewer new loans. Likewise, higher delinquencies and net loss rates are negatively related to bank loan growth, which is expected given the serial correlation in charge-offs that subtract directly from loan growth, the likelihood that banks experiencing losses might reduce loan supply, and the probability that creditworthy borrowers in distressed areas would demand fewer loans. Unused commitments had a positive effect on bank loan growth, signifying that the extent of draws on committed credit lines exceeded banks' ability to offset that growth with tighter standards in spot loan markets.

The Kleibergen-Paap rk LM statistic (row 17) suggests that we reject the null hypothesis that the equation is under-identified for the CUE estimation shown in the second column. This indicates that the excluded regressors are relevant and correlated with the endogenous regressor; i.e., the Hq_dseats variable is a relevant instrument. 
After instrumenting for TGS in the loan growth equation, the magnitude and significance of the coefficients on a number of key variables change in important ways from the OLS results. Most importantly, the coefficient estimate associated with TGS becomes fairly large and positive when we address the endogeneity bias. Combining these results together, our findings suggests that even though the IV estimation yields a positive coefficient associated with TGS, suggesting that an increase in government funding prompts banks to increase their loans, the estimated impact is insignificant. One reason for that insignificance seems to be that the predicted value of government support is collinear with bank size, because the coefficient on $\log ($ Assets $)$, which had been highly significant in the OLS equation, becomes insignificant in the IV equation.

Table 3c shows the results of a statistical test of the null hypothesis that bank's allocations under the TGS programs was exogenous. The tests suggest that it is endogenous, justifying our treatment of TGS as an endogenous variable throughout the analysis.

\section{Table 3c: Testsof Endogeneity based on CUE}

\begin{tabular}{l|l|l}
\hline \hline Endogenous Regressor & Test Statistic & P-value \\
\hline$(T G S)_{i, \mathrm{t}} /(\text { Assets })_{i . t-1}$ & Chi-sq $(1)=1.72$ & 0.19 \\
\hline \hline
\end{tabular}

\subsection{Cross Sectional Analysis}

In this section, we consider a cross sectional analysis similar to Li (2013). The dependent variable is constructed as loan growth over the first two years after a program is introduced. For the CPP, for example, the majority of which was distributed by the end of the first quarter of 2009, we look at loan growth over 2009 and 2010. The key independent variable is the maximum amount of funding that the bank received from the particular government support 
program being studied at any point in the two-year window of the dependent variable. ${ }^{18}$ So, for the CPP, we regress loan growth in 2009 and 2010 on the maximum between 2009 and 2010 of the ratio of quarterly average outstanding CPP funds to beginning of quarter total assets. Most other control variables are set to their values as of the third quarter of 2008 , the period before the TARP program was introduced. Controls for macroeconomic conditions in the bank's markets in the quarter before TARP was introduced-2008:Q3 — and over the 2009-2010 period are also included to control for loan demand. The latter variables are included on the assumption that actions of an individual bank cannot influence overall employment and house price growth contemporaneously.

In a cross sectional framework, we can exploit another instrument, which is the status of whether a bank was publicly traded during the sample period. We believe that this may be a powerful instrument particularly for the CPP funding because confusion over whether banks organized as subchapter S corporations or mutual savings banks were eligible for CPP funds may have caused all banks that were not publicly traded to be slow in requesting funds. ${ }^{19}$ By the time

\footnotetext{
${ }^{18}$ One potential strength of using the maximum value held by the bank in any given quarter during the sample period is that many banks repaid their CPP funds over the course of 2009 and 2010. Thus, in the panel dataset, CPP funds appear to only be outstanding in a small number of quarters. However, banks that wanted repay CPP funds had to show the ability to raise sufficient capital or long-term debt in public capital markets before they were allowed to do so. To the extent that the existence of the CPP made it subsequently easier to raise funds in public capital markets then the CPP was supporting lending beyond the point where it had been repaid.

${ }^{19}$ The U.S. Treasury Department clarified the eligibility of subchapter S corporations for TARP funds on January 9 , 2009. See, https://www.treasury.gov/initiatives/financial-stability/TARP-Programs/bank-investment-
} programs/cap/Documents/scorp-term-sheet.pdf. Mutual Savings Banks were not eligible to receive TARP funds 
the ambiguity was addressed in the first third of 2009, the acute phase of the crisis had receded, new conditions - such as executive-pay restrictions - had been added to the program, and the program had become very unpopular with the public. Thus, those banks were much less likely to have applied for CPP funds than banks that were immediately clear on their eligibility, despite prevailing conditions in bank lending markets. In addition, the decision to be a public firm is predetermined at the outset of crisis, not correlated with changes in loan demand or loan supply from 2009 to 2012. One factor determining whether a firm is publicly traded may be the owners' reluctance to subject themselves to the higher degree of regulation for public firms, and that reluctance to invite scrutiny from supervisors also may be an exogenous factor affecting the bank's willingness to participate in other government support programs as well. Thus, we test this instrument for all five programs.

We estimate equation (2), which is very similar to equation (1) except that (i) the data is not in a panel format and (ii) we focus on the individual components of TGS and treat them as an endogenous variable. For instance, for the CPP, we have:

$\Delta \log (\text { Loans })_{t}=\alpha+\beta_{1} \times(C P P)_{t} / T A_{t-1}+\beta_{2} \times(T A F+T D W)_{t-1} / T A_{t-1}$

$+\beta_{3} \times(\text { Managed Liabilitie s })_{t-1} / T A_{t-1}+\beta_{4} \times(\text { Core Deposits })_{t} / T A_{i, t-1}+\beta_{5} \times(\text { Leverage Ratio })_{t-1}$

$+\beta_{6} \times(\text { REcommit })_{t-1} /(\text { Commit }+T A)_{t-1}+\beta_{7} \times(\text { Othcommit })_{t-1} /(\text { Commit }+T A)_{t-1}$

$+\beta_{8} \times(\text { Illiquid Assets })_{t-1} / T A_{t-1}+\beta_{9} \times(\text { RiskyRE })_{t-1} / T A_{t-1}$

$+\beta_{10} \times(\text { Delinquency ratio })_{t-1}+\beta_{11} \times$ Net chargeoff rate ${ }_{t-1}+\beta_{12} \times \log \left(\right.$ Assets $\left._{t-1}\right)$

$+\beta_{13} \times(\text { Employment Growth })_{t-1}+\beta_{14} \times(\text { Housing })_{t-1}+\varepsilon_{t}$

The first column in Table 4a shows the results from the first stage regression for CPP. Consistent with our expectations, the dummy variable that captures whether a bank is publicly traded (row 2) is highly significant with a positive sign, suggesting that those banks that were

until April 7, 2009. See, https://www.treasury.gov/initiatives/financialstability/reports/Documents/105aReport_042009.pdf 
public had easier access to TARP funds or were predisposed to accept outside equity investments for reasons that were unrelated to cyclical changes in loan demand. Meanwhile $\mathrm{Hq}_{\text {d }}$ sseats (row 1) was not significant in the cross section, nor was prior participation in the TAF or TDW programs. As expected, banks that had higher ratios of tangible common equity (TCE ratio) were less likely to access CPP funds, and banks with higher loss rates on their delinquent loans were more likely to do so.

Table 4a: First Stage Regression

\begin{tabular}{|c|c|c|c|c|c|}
\hline & & I. CPP & $\begin{array}{l}\text { II.(TAF } \\
+ \text { TDW) }\end{array}$ & $\begin{array}{l}\text { III.SBLF } \\
\end{array}$ & IV.DGP \\
\hline & $H q_{-}$dseats $_{i}$ (Instrument) & $\begin{array}{c}0.00 \\
(-0.50)\end{array}$ & $\begin{array}{l}-0.02 \\
(-1.05)\end{array}$ & $\begin{array}{c}0.00 \\
(-1.35)\end{array}$ & $\begin{array}{l}0.00 \\
1.04)\end{array}$ \\
\hline 2. & Dummy_Stock (Instrument) & $\begin{array}{c}0.97 * * \\
(7.03)\end{array}$ & $\begin{array}{c}0.36 \\
(1.29)\end{array}$ & $\begin{array}{c}-0.10 \\
(-1.55)\end{array}$ & $\begin{array}{c}0.04 \\
0.72)\end{array}$ \\
\hline 3. & $(C P P)_{\mathrm{t}-1} /(\text { Assets })_{t-1}$ & -- & -- & $\begin{array}{c}0.13 * * \\
(3.99)\end{array}$ & -- \\
\hline 4. & $\left(T A F_{t-1}+T D W_{t-1}\right) /(\text { Assets })_{t-1}$ & $\begin{array}{c}0.00 \\
(-0.01)\end{array}$ & -- & -- & $\begin{array}{c}-0.01 \\
(-0.55)\end{array}$ \\
\hline 5. & Loan Growth $_{t-1}$ & $\begin{array}{c}0.00 \\
(0.16)\end{array}$ & $\begin{array}{c}-0.01 \\
(-0.22)\end{array}$ & $\begin{array}{c}0.01 \\
(1.58)\end{array}$ & $\begin{array}{c}0.00 \\
0.74)\end{array}$ \\
\hline 6. & $\left(\right.$ Managed Liabilitie $\left.s_{t-1}\right) /(\text { Assets })_{t-1}$ & $\begin{array}{c}-0.01 \\
(-0.59)\end{array}$ & $\begin{array}{c}0.02 \\
(1.19)\end{array}$ & $\begin{array}{l}0.01 * \\
(1.94)\end{array}$ & $\begin{array}{c}0.00 \\
0.22)\end{array}$ \\
\hline 7. & $\left(\right.$ Core Deposits $\left._{t-1}\right) /(\text { Assets })_{t-1}$ & $\begin{array}{c}-0.01 \\
(-1.88)\end{array}$ & $\begin{array}{c}0.02 \\
(1.58)\end{array}$ & $\begin{array}{c}0.00 \\
(1.54)\end{array}$ & $\begin{array}{c}0.00 \\
-0.36)\end{array}$ \\
\hline 8. & TCE Ratio t $-1_{1}$ & $\begin{array}{c}-0.09 * * \\
(-3.91)\end{array}$ & $\begin{array}{c}-0.05 \\
(-0.99)\end{array}$ & $\begin{array}{c}-0.01 \\
(-1.09)\end{array}$ & $\begin{array}{c}0.00 \\
-0.04)\end{array}$ \\
\hline 9. & Recommit Ratio Re $_{t-1}$ & $\begin{array}{c}0.02 \\
(0.80)\end{array}$ & $\begin{array}{c}0.04 \\
(0.99)\end{array}$ & $\begin{array}{c}0.01 \\
(0.66)\end{array}$ & $\begin{array}{l}0.01 \\
1.17)\end{array}$ \\
\hline 10. & Other Commit Ratio $t-1$ & $\begin{array}{c}-0.01 \\
(-1.01)\end{array}$ & $\begin{array}{c}-0.01 \\
(-0.49)\end{array}$ & $\begin{array}{c}0.00 \\
(0.70)\end{array}$ & $\begin{array}{l}0.01 \\
1.61)\end{array}$ \\
\hline 11. & $(\text { Illiquid Assets })_{t-1} /(\text { Assets })_{t-1}$ & $\begin{array}{c}-0.01 \\
(-1.31)\end{array}$ & $\begin{array}{c}0.01 \\
(0.55)\end{array}$ & $\begin{array}{c}0.00 \\
(0.38)\end{array}$ & $\begin{array}{c}0.00 \\
-0.58)\end{array}$ \\
\hline 12. & $(\text { RiskyRE })_{t-1} /(\text { Assets })_{t-1}$ & $\begin{array}{l}0.02 * \\
(1.72)\end{array}$ & $\begin{array}{c}0.01 \\
(0.46)\end{array}$ & $\begin{array}{l}-0.01^{*} \\
(-1.84)\end{array}$ & $\begin{array}{c}0.00 \\
0.99)\end{array}$ \\
\hline 13. & $(\text { Delinquencies })_{t-1} /(\text { Tier } 1 \text { Common })_{t-1}$ & 0.00 & 0.00 & 0.00 & 0.00 \\
\hline
\end{tabular}




\begin{tabular}{|c|c|c|c|c|c|}
\hline & & $(1.13)$ & $(0.35)$ & $(-0.80)$ & $(1.30)$ \\
\hline 14. & $(\text { Net chargeoff rate })_{t-1}$ & $\begin{array}{c}0.01 * * \\
(2.16)\end{array}$ & $\begin{array}{c}-0.01 \\
(-0.28)\end{array}$ & $\begin{array}{c}0.01 \\
(1.51)\end{array}$ & $\begin{array}{c}0.00 \\
(-0.22)\end{array}$ \\
\hline 15. & $\log (\text { Assets })_{t-1}$ & $\begin{array}{c}0.06 \\
(0.95)\end{array}$ & $\begin{array}{c}0.40 * * \\
(3.15)\end{array}$ & $\begin{array}{l}-0.04 * \\
(-1.67)\end{array}$ & $\begin{array}{c}0.16^{* *} \\
(6.46)\end{array}$ \\
\hline 16. & $(\text { Employment Growth })_{t-1}$ & $\begin{array}{c}-0.06 \\
(-1.28)\end{array}$ & $\begin{array}{c}0.03 \\
(0.23)\end{array}$ & $\begin{array}{c}0.02 \\
(0.84)\end{array}$ & $\begin{array}{c}0.00 \\
(-0.09)\end{array}$ \\
\hline 17. & $(\text { Housing })_{t-1}$ & $\begin{array}{c}0.01 \\
(0.21)\end{array}$ & $\begin{array}{l}0.11^{*} \\
(0.86)\end{array}$ & $\begin{array}{c}0.07 \\
(0.80)\end{array}$ & $\begin{array}{c}0.02 \\
(0.90)\end{array}$ \\
\hline 18. & $(\text { Cumulative Employment })_{09-10}$ & $\begin{array}{c}0.01 \\
(0.08)\end{array}$ & $\begin{array}{c}-0.07 \\
(-0.55)\end{array}$ & $\begin{array}{c}0.02 \\
(0.70)\end{array}$ & $\begin{array}{c}0.00 \\
(-0.11)\end{array}$ \\
\hline 19. & $(\text { Cumulative Housing })_{09-10}$ & $\begin{array}{c}-0.22 \\
(-1.42)\end{array}$ & $\begin{array}{c}-0.49 \\
(-1.72)\end{array}$ & $\begin{array}{c}-0.06 \\
(-0.74)\end{array}$ & $\begin{array}{c}-0.04 \\
(-0.65)\end{array}$ \\
\hline 20. & Number of observations & 338 & 329 & 322 & 338 \\
\hline 21. & R-squared & 0.33 & 0.13 & 0.13 & 0.28 \\
\hline
\end{tabular}

Columns II-IV of Table 4a show the first-stage regressions of the rest of the government support programs. The dependent variables are the maximum quarterly value over the 2007:Q3 to 2012:Q4 sample period of the ratio of the specific type of government funding to total assets. Unfortunately, neither of the proposed instruments is successful in explaining these programs (rows 1 and 2), which means that we are unable to measure their effect on loan growth.

However, these regressions are still helpful in illustrating the determinants of participation in the various crisis-era term funding programs.

Control variables are from the quarter before the program was introduced: 2007:Q2 for TDF and TAF (column 1) and 2008:Q2 for DGP (column 3), except for branch-weighted growth of employment and house prices in markets in which the banks have branches, which are for 2007:Q3 and 2008:Q3 respectively. Control variables for the SBLF (column2) are from 2010:Q3, and this regression is restricted only to banks with total assets less than $\$ 10$ billion because the program was focused on small bank holding companies. 
The striking feature of these results is that participation in these programs is explained by a small set of variables. Asset size is the only variable that is significant in the DGP regression, which has a relatively high $\mathrm{R}$-squared of 0.28 , reflecting the extensive use of the program by the largest bank holding companies. Asset size is also significant and positive in the TAF+TDW regression, because the TAF was shown earlier to be dominated by large banks and TDW participation by small banks was limited. Meanwhile we observe that SBLF is strongly positively related to CPP borrowing, a result that is not surprising because of the option to replace CPP funds with SBLF. The lack of significance of other variables in this equation suggests that most SBLF participation simply replaced CPP and helps support the results of the panel regression in the previous section that combines all of the programs.

Despite the aggregate evidence shown earlier that suggested successive programs replaced early programs, after controlling for other characteristics, banks' usage of other programs does not seem to be determined by their participation in prior programs. As was the case for the CPP, participation in the TAF or TDW as of 2008:Q3 did not help determine participation in the DGP. These results may reflect the different characteristics of the programs, with the TDW and TAF providing short-term funding and the CPP and DGP providing longerterm funding. Banks may have independent needs for each of those types of funding.

Turning to loan growth, the first column in Table $4 \mathrm{~b}$ shows the results from the OLS regression that treats CPP exogenously while the second column shows the second stage of the IV estimation. Looking at the coefficient associated with CPP (row 1) we note that the coefficient becomes fairly large and positive when we address the endogeneity bias although both estimates are statistically insignificant. This finding is very similar to our results for the panel obtained for the TGS variable (Table 3). Hence, the main finding from the panel regression 
for all government support programs remain robust under different techniques and a different instrument, and with a focus on one of the two largest five components of TGS in the cross section analysis.

Table 4b: Loan Growth Regression

\begin{tabular}{|c|c|c|c|}
\hline & & I.OLS & II.IV \\
\hline & $(C P P)_{\mathrm{t}} /(\text { Assets })_{t-1}$ & $\begin{array}{l}-0.06 \\
(-0.29)\end{array}$ & $\begin{array}{l}0.46 \\
(1.33)\end{array}$ \\
\hline 2. & LoanGrowth $_{t-1}$ & $\begin{array}{l}0.12 * * \\
(3.74)\end{array}$ & $\begin{array}{l}0.11^{* *} \\
(3.59)\end{array}$ \\
\hline 3. & $\left(T A F_{t-1}+T D W_{t-1}\right) /\left(\right.$ Assets $_{t-1}$ & $\begin{array}{l}-0.02 \\
(-0.30)\end{array}$ & $\begin{array}{l}-0.02 \\
(-0.31)\end{array}$ \\
\hline 4. & 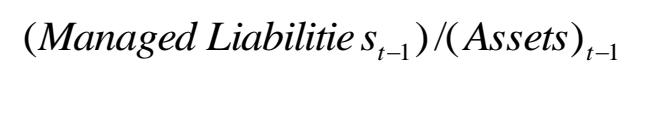 & $\begin{array}{l}0.01 \\
(0.43)\end{array}$ & $\begin{array}{l}0.01 \\
(0.57)\end{array}$ \\
\hline 5. & $\left(\right.$ Core Deposits $\left._{t-1}\right) /(\text { Assets })_{t-1}$ & $\begin{array}{l}0.01 \\
(0.76)\end{array}$ & $\begin{array}{l}0.02 \\
(1.07)\end{array}$ \\
\hline 6. & TCE Ratio R-1 $_{t}$ & $\begin{array}{l}0.10 \\
(1.37)\end{array}$ & $\begin{array}{l}0.15 * * \\
(2.14)\end{array}$ \\
\hline 7. & Recommit Ratio $_{t-1}$ & $\begin{array}{l}-0.04 \\
(-0.87)\end{array}$ & $\begin{array}{l}-0.04 \\
(-0.81)\end{array}$ \\
\hline 8. & Other Commit Ratio $t-1$ & $\begin{array}{l}-0.02 \\
(-1.38)\end{array}$ & $\begin{array}{l}-0.02 \\
(-0.84)\end{array}$ \\
\hline 9. & $(\text { Illiquid Assets })_{t-1} /(\text { Assets })_{t-1}$ & $\begin{array}{l}0.02 \\
(1.26)\end{array}$ & $\begin{array}{l}0.02 \\
(1.15)\end{array}$ \\
\hline 10. & $(\text { RiskyRE })_{t-1} /(\text { Assets })_{t-1}$ & $\begin{array}{l}-0.05 * * \\
(-2.48)\end{array}$ & $\begin{array}{l}-0.05 * * \\
(-2.47)\end{array}$ \\
\hline 11. & $(\text { Delinquencies })_{t-1} /(\text { Tier } 1 \text { Common })_{t-1}$ & $\begin{array}{l}-0.03 * * \\
(-4.19)\end{array}$ & $\begin{array}{l}-0.03 * * \\
(-4.30)\end{array}$ \\
\hline 12. & $(\text { Net chargeoff rate })_{t-1}$ & $\begin{array}{l}-0.02 \\
(-0.88)\end{array}$ & $\begin{array}{l}-0.02 \\
(-1.30)\end{array}$ \\
\hline 13. & $\log (\text { Assets })_{t-1}$ & $\begin{array}{l}0.07 \\
(0.55)\end{array}$ & $\begin{array}{l}-0.03 \\
(-0.19)\end{array}$ \\
\hline 14. & $(\text { Employment Growth })_{t-1}$ & $\begin{array}{l}0.11 \\
(1.06)\end{array}$ & $\begin{array}{l}0.16 \\
(1.60)\end{array}$ \\
\hline 15. & $(\text { Housing })_{t-1}$ & $\begin{array}{l}0.11 \\
(0.87)\end{array}$ & $\begin{array}{l}0.12 \\
(0.98)\end{array}$ \\
\hline 16. & (Cumulative Employment $)_{09-10}$ & $\begin{array}{l}0.20 \\
(1.00)\end{array}$ & $\begin{array}{l}0.20 \\
(1.03)\end{array}$ \\
\hline
\end{tabular}




\begin{tabular}{l|l|l} 
17. $\quad$ (Cumulative Housing $)_{09-10}$ & $\begin{array}{l}-0.10 \\
(-0.29)\end{array}$ & $\begin{array}{l}0.00 \\
(0.01)\end{array}$ \\
\hline 18. Number of observations & 339 & 338 \\
\hline \hline t-ratios based on robust standard errors are reported in parenthesis under coefficient \\
estimates $* * / *$ indicates significance at $95 / 90$ percent level of confidence respectively.
\end{tabular}

\section{Conclusion}

We have constructed a comprehensive dataset of banks' participation in five different crisis-era programs designed to support financial stability and increase loan supply. We show that at various times banks used these programs as substitutes or complements, so that results based on a study of the effect of one program in isolation may be incomplete or misleading. In addition, we show that usage of the DGP was most skewed toward the largest banks, while the CPP was used extensively by midsize and smaller institutions, especially after the middle of 2009.

In an application of this dataset, we study the combined effect of participation in the CPP, the DGP, the SBLF, TAF, and TDW. Our findings suggest that banks that participated in at least one of those programs similar loan growth to banks that did not. The effect is identified by first using an instrumental variable based on the dominant political affiliation in areas where the bank operates branches, an approach similar to those used by other authors in this literature, but applied to the more comprehensive measure of government support and in a panel dataset spanning 2007:Q3 to 2012:Q4. Our results remain robust in a cross-sectional framework that isolates the effect of the CPP, and where we exploit an unintended delay in the availability of CPP funds for certain classes of non-publicly traded banks that led to lower participation among those groups as an additional instrumental variable. The key caveat to those results is that the programs almost surely had an additional benefit of reducing the number of bank failures, and that benefit cannot be quantified separately within this analytical framework. 


\section{Appendix}

\section{CPP data description:}

The Capital Purchase Program (CPP) was part of the Troubled Asset Relief Program (TARP), which became law in October 2008. Under the CPP, the U.S. Treasury provided capital ( $\$ 204.9$ billion) to certain financial institutions in exchange for preferred stock or debt securities, beginning October $28^{\text {th }}, 2008$. This program was designed to secure financial stability and maintain confidence in participating financial institutions among counterparties to such institutions. The final disbursement from the CPP facility originated on December $29^{\text {th }}, 2009$. Another TARP program, the Targeted Investment Program (TIP), was established in December 2008 to stabilize two firms considered systemically important: Citigroup and Bank of America. Each firm received $\$ 20$ billion in exchange for preferred stock. Treasury created the Community Development Capital Initiative (CDCI) in February 2010, which was also a component of TARP. This program was much smaller in size ( $\$ 570$ million disbursed) than the CPP or TIP and it provided capital specifically to Community Development Financial Institutions (CDFIs), such as small banks, thrifts, and credit unions. Many CDFIs were CPP participants in good standing and were allowed to exchange CPP securities for CDCI securities, which had more favorable financing terms. Financing under the CPP, CDCI, and TIP programs totaled $\$ 245.5$ billion.

We obtained raw public CPP, CDCI, and TIP data from the U.S. Treasury and aggregated data from all three programs into a single data set. Using National Information Center (NIC) data and Treasury's raw data fields for participant name, city, and state, we identified unique RSSD identifiers of the participants and their ultimate top holders. In many cases, identification of correct RSSD numbers required a manual selection process. We created a time series of each unique top holder's holdings of the sum of CPP, CDCI and TIP securities, adjusted for 
transformative events such as mergers and acquisitions. As of December 31, 2012, \$234.4

billion had been repaid by participating entities and write-offs totaled $\$ 3.9$ billion, with $\$ 7.2$ billion outstanding.

\section{SBLF data description:}

The Small Business Lending Fund (SBLF) was established as a result of the Small Business Jobs Act of 2010, passed in December 2010, to provide capital to certain community banks and community development loan funds (CDLFs). The fund was administered by the U.S. Treasury, which provides their raw SBLF data to the public. We excluded CDLF participants from our data. A total of $\$ 3.9$ billion was disbursed to 281 unique community banks. Using NIC data and Treasury's raw data fields for participant name, city, and state, we identified unique RSSD identifiers of the participants and their ultimate top holders. In many cases, identification of correct RSSD numbers was a manual process. We created a time series of each unique top holder's holdings of SBLF debt, adjusted for transformative events such as mergers and acquisitions. Treasury had received $\$ 120$ million in cumulative repayments as of December $31^{\text {st }}, 2012$, leaving $\$ 3.8$ billion aggregate debt outstanding as of that date.

\section{DGP data description:}

The FDIC initiated the Temporary Liquidity Guarantee Program (TLGP) on October 14, 2008 in an effort to bring financial stability to the economy. This program consisted of two components: The Transaction Account Guarantee Program (TAGP) and the Debt Guarantee Program (DGP). Under the DGP, the FDIC fully guaranteed some senior unsecured debt instruments issued by financial institutions for up to three years from the date of issuance. All 
eligible debt matured on or before December 31, 2012. Debt instruments were originated between October 14, 2008 and October 31, 2009.

The FDIC avails DGP data to the public. In addition, the FDIC provided us with RSSD identifiers for many of the participants upon a FOIA request in order to identity participating institutions. We manually matched remaining participating institutions to correct RSSD IDs by comparing entity names and locations in FDIC's data with corresponding data managed by the NIC data. We also used NIC data to determine ultimate top holders for each participating entity. We created a time series of each unique top holder's debt secured by the FDIC under the DGP, adjusted for transformative events such as mergers and acquisitions. Short-term debt instruments, those with maturities less than one year, accounted for about $96 \%$ of the DGPparticipating instruments and about $51 \%$ of the volume of those debt instruments. A total of $\$ 618$ billion of debt received an FDIC guaranty, but that figure double counts individual issuance amounts each time an entity rolled over its FDIC-guaranteed debt upon maturity. The sum of each unique top holder's maximum daily balance of guaranteed liabilities totals $\$ 397$ billion.

\section{Term Discount Window data description:}

From August 2007 to March 2010 the Federal Reserve Board provided additional liquidity to the banking system in the form of term lending via the discount window's primary credit program. Those eligible to borrow from the discount window through the Federal Reserve's standing overnight primary credit program could participate in the temporary term discount window program. We considered term discount window borrowings with maturities of 5 calendar days or more. The data were constructed by researchers at the Federal Reserve using information made public by the Federal Reserve via Freedom of Information Act (FOIA) 
requests. We determined the top holder of each borrowing entity and created a time series of each unique top holder's holdings of term discount window funds. Many participating institutions rolled over these funds upon maturity. The sum of each unique top holder's maximum daily balance of term discount window funds totals $\$ 167$ billion.

\section{Term Auction Facility data description:}

The Federal Reserve Board of Governors approved the establishment of the Term Auction Facility (TAF) to provide liquidity to unsecured interbank markets. Under this facility, the Federal Reserve began auctioning term funds to depository institutions on December 17, 2007. The last auction occurred on XX, and those loans matured on YY. Entities eligible to access the primary credit discount window and found in a sound condition were eligible to borrow TAF funds. We included only domestic depository institutions in our data, though a large share of the TAF program was disbursed to support the U.S. lending and other activities of branches and agencies of foreign banks. We determined the top holder of each participating entity and created a time series of each unique top holder's holdings of TAF funds. Many participating institutions rolled over TAF funds upon maturity. The sum of each unique top holder's maximum daily balance of TAF funds totaled $\$ 451$ billion. 


\section{References}

Angrist, J., and Krueger, A., 2001, Instrumental Variables and the Search for Identification: From Supply and Demand to Natural Experiments, Journal of Economic Perspectives 15, 69-85.

Ashcraft, A., Bech, A., and Scott, W., 2009, The Federal Home Loan Bank System: The Lender of Next-to-Last Resort?, Federal Reserve Bank of Atlanta, Working paper no: 2009-4.

Aubuchon, Craig P. and David C. Wheelock, 2010, The Geographic Distribution and Characteristics of U.S. Bank Failures, 2007-2010: Do Bank Failures Still Reflect Local Economic Conditions?, Federal Reserve Bank of St. Louis Review, 92(5), pp. 395-415.

Bassett, William and Francisco Covas, 2013, Capital Constraints and Bank Lending Standards, Board of Governors of the Federal Reserve System, unpublished manuscript

Bassett, William, Mary Beth Chosak, John Driscoll, and Egon Zakrajsek, 2014, The Macroeconomic Effects of Bank Lending Standards, Journal of Monetary Economics, Forthcoming.

Bassett, William F.; Simon Gilchrist; Gretchen C Weinbach; and Egon Zakrajsek, 2011, Improving Our Ability to Monitor Bank Lending, in Risk Topography: Systemic Risk and Macro Modeling, Markus K. Brunnermeier and Arvind Krishnamurthy, editors, National Bureau of Economic Research (NBER)

Bell, F., and Murphy, N., 1968, Economies of Scale and Division of Labor in Commercial Banking, Southern Economic Journal 35, No. 2, 131-139

Benston, G., 1972, Economies of Scale of Financial Institutions, Journal of Money, Credit and Banking 4, No. 2, 312-341.

Berger, B., Black, L., Bouwman, C., Dlugosz., J., 2012a. Pushing on a String: Did Federal Reserve Lending Help Resolve the Financial Crisis?, unpublished manuscript.

Berger, Allen N. and Bouwman, Christa H. S. and Kick, Thomas K. and Schaeck, Klaus, 2016. Bank Liquidity Creation Following Regulatory Interventions and Capital Support. Journal of Financial Intermediation 26, 115-141.

Berger, Allen. N., Imbierowicz, B. and Rauch, C. (2016), The Roles of Corporate Governance in Bank Failures during the Recent Financial Crisis. Journal of Money, Credit and Banking, 48: 729-770.

Berger, Allen N. and Roman, Raluca A., 2015. Did TARP Banks Get Competitive Advantages? Journal of Financial and Quantitative Analysis (JFQA), Forthcoming. 
Berger, Allen N. and Roman, Raluca A., 2016. Did Saving Wall Street Really Save Main Street? The Real Effects of TARP on Local Economic Conditions. Journal of Financial and Quantitative Analysis (JFQA), Forthcoming.

Berrospide, J., and Edge, R., 2010. The Effects of Bank Capital on Lending: What do We Know, and What Does It Mean?, International Journal of Central Banking, 6(4): 5-54.

Bernanke, B., 1983. Irreversibility, Uncertainty, and Cyclical Investment, The Quarterly Journal of Economics 98(1), 85-106

Bernanke, B., and Blinder, B. 1988. Credit, Money, and Aggregate Demand, American Economic Review 78, 435-439.

Bernanke, B., and Blinder, A., 1992. The Federal Funds Rate and the Channels of Monetary Transmission, American Economic Review 82(4), 901-921

Bernanke, B., Gertler, M. and Gilchrist, S., 1999. The financial accelerator in a quantitative business cycle framework, Handbook of Macroeconomics, in: J. B. Taylor \& M. Woodford (ed.), Handbook of Macroeconomics, edition 1, volume 1, chapter 21, 13411393

Beyazitova, D., and Shivdasani, A., 2012. Assessing TARP, The Review of Financial Studies 25, 377-407.

Black, L., and Hazelwood, L., 2013. The Effect of TARP on Bank Risk Taking, Journal of Financial Stability 9(4), 790-803.

Carhart, Mark M. (1997). "On Persistence in Mutual Fund Performance". Journal of Finance 52 (1): $57-82$

Cadman, B., Carter, M.E., Lynch, L.J., 2012. Executive pay restrictions: do they restrict firms' willingness to participate in TARP? Journal of Business, Finance \& Accounting 39, 948970 .

Calem, Paul, Francisco Covas, and Jason Wu, 2013. The Impact of the 2007 Liquidity Shock on Bank Jumbo Mortgage Lending. Journal of Money, Credit and Banking 45, 59-91.

Carpenter, S., and Demiralp, S., 2012. Money, Reserves, and the Transmission of Monetary Policy: Does the Money Multiplier Exist?, Journal of Macroeconomics, 34, 59-75.

Carpenter, S., Demiralp, S., and Eisenschmidt, J., 2014. The Financial Crisis, Bank Lending, and the Effectiveness of Lending Facilities: The experiences of the Federal Reserve and the European Central Bank, Journal of Economic Dynamics and Control, forthcoming.

Christensen, J. H. E., Lopez, J.A., and Rudebusch, G.D., 2009. Do Central Bank Liquidity Facilities Affect Interbank Lending Rates?, FRBSF Working Paper 2009-13 (June). 
Cornett, M., McNutt, J., Strahan, P., Tehranian, H., 2011. Liquidity Risk Management and Credit Supply in the Financial Crisis, Journal of Financial Economics 101, 297-312.

Cornett, M. M., Li, L., Tehranian, H., 2013. The Performance of Banks around the Receipt and Repayment of TARP Funds: Over-Achievers versus Under-Achievers Journal of Banking and Finance, March 37 (3), 730-46.

Coval, J. and Thakor, A., 2005. Financial Intermediation as a Beliefs-bridge between Optimists and Pessimists, Journal of Financial Economics 75, 535-569.

Diamond, D. and Rajan, R., 2000. A Theory of Bank Capital, Journal of Finance 55, 2431-2465.

Duchin, R. and Sosyura, D., 2012. The Politics of Government Investment, Journal of Financial Economics, 106 (1), pp. 24-48.

Duchin, R. and Sosyura, D., 2014. Safer ratios, riskier portfolios: Banks' response to government aid, Journal of Financial Economics, Volume 113, Issue 1, Pages 1-28.

English, W., and Nelson, W., 1998, Profits and Balance Sheet Developments at U.S. Commercial Banks in 1997, Federal Reserve Bulletin, June, 391-419.

Gaby, Max; Walker, David A., 2011. Impacts of TARP on Financial Institutions, Journal of Applied Finance, 21 (2), 73-87

Hahn, J., Hausman, J., and Kuersteiner, G.,2004. Estimation with Weak Instruments: Accuracy of Higher-order Bias and MSE Approximations, Econometrics Journal, Royal Economic Society $7(1), 272-306$

Oneil Harris, Daniel Huerta, Thanh Ngo, The impact of TARP on bank efficiency, Journal of International Financial Markets, Institutions and Money, Volume 24, April 2013, Pages 85-104

Ivashina, Victoria, and David Scharfstein. 2010. Bank Lending During the Financial Crisis of 2008, Journal of Financial Economics 97(3), 319-338

Jordan, Dan J., Douglas Rice, Jacques Sanchez, and Donald H. Wort, Explaining bank marketto-book ratios: Evidence from 2006 to 2009, Journal of Banking \& Finance 35, 2047 2055

Judosn, Ruth, and Ann Owen. 1999. Estimating Dynamic Panel Data Models: A Guide for Macroeconomists, Economic Letters 65, 9-15.

Kashyap, Anil, and Jeremy Stein. 2000. What Do a Million Observations on Banks say About the Transmission of Monetary Policy?, American Economic Review 90, 407-428. 
Kelejian, H., 1971. Two-Stage Least Squares and Econometric Systems Linear in Parameters but Nonlinear in the Endogenous Variables. Journal of the American Statistical Association 66, 373-374.

Kishan, R., and Opiela, T. 2000. Bank Size, Bank Capital, and the Bank Lending Channel, Journal of Money, Credit, and Banking 32, 121-141.

Li, L., 2013. TARP Funds Distribution and Bank Loan Supply, Journal of Banking and Finance 37 (12), 4777-92

Loutskina, Elena. (2010) "The Role of Securitization in Bank Liquidity and Funding Management.” Journal of Financial Economics, 100, 663-84.

Madestam, Andreas, Daniel Shoag, Stan Veuger, and David Yanagizawa-Drott, 2013."Do Political Protests Matter? Evidence from the Tea Party Movement." The Quarterly Journal of Economics 128 (4), 1633-1685.

McAndrews, J., Sarkar, A., and Wang, Z., 2008. The Effect of the Term Auction Facility on the London Inter-Bank Offered Rate, FRB New York Staff Report 335.

Ng, Jeffrey, Florin Vasvari, and Regina Wittenberg-Moerman. 2011 "The Impact of TARP's Capital Purchase Program on the Stock Market Valuation of Participating Banks" unpublished manuscript, http://faculty.chicagobooth.edu/Regina.Wittenberg\%20moerman/research/pdf/ImpactT ARP'sCapitalPurchaseProgram.pdf

Puddu Stefano and Andreas Walchli, 2012, TAF Effect on Liquidity Risk Exposure. Working Paper, University of Neuchâtel.

Puddu Stefano and Andreas Walchli, 2013, TARP Effect on Bank Lending Behaviour: Evidence from the last Financial Crisis. Working Paper, Université de Neuchâtel.

Roodman, D., 2006. How to do xtabond2: an introduction to "Difference" and "System" GMM in Stata. Center for Global Development Working Paper Number 103.

Schaffer, M.E., 2010. xtivreg2: Stata module to perform extended IV/2SLS, GMM and $\mathrm{AC} / \mathrm{HAC}, \mathrm{LIML}$ and $\mathrm{k}$-class regression for panel data models, http://ideas.repec.org/c/boc/bocode/s456501.html

Taliaferro, R., 2009. How Do Banks Use Bailout Money? Optimal Capital Structure, New Equity, and the TARP. SSRN Working Paper. <http://ssrn.com/abstract=1481256>.

Taylor, J., and Williams, J., 2009. A Black Swan in the Money Market, American Economic Journal: Macroeconomics 1(1), 58-83. 
Thornton, D., 2009. The Fed, Liquidity, and Credit Allocation, Federal Reserve Bank of St. Louis Review 91(1), 13-21.

Thornton, D., 2011, What Does the Change in the FOMC's Statement of Objectives Mean?, Federal Reserve Bank of St. Louis Economic Synopses 1.

Veronesi, P., Zingales, L., 2010. Paulson's gift, Journal of Financial Economics 97, 339-368.

Wilson, L., Wu, Y.W., 2012. Escaping TARP. Journal of Financial Stability 8, 32-42.

Wu, T., 2008, On the Effectiveness of the Federal Reserve's New Liquidity Facilities, Federal Reserve Bank of Dallas Working Paper 0808 